\title{
Effects of the Chop Lengths of Alfalfa Silage and Oat Silage on Feed Intake, Milk Production, Feeding Behavior, and Rumen Fermentation of Dairy Cows
}

\author{
S. K. Bhandari, S. Li, K. H. Ominski, K. M. Wittenberg, and J. C. Plaizier ${ }^{1}$ \\ Department of Animal Science, University of Manitoba, Winnipeg, Manitoba, R3T 2N2 Canada
}

\begin{abstract}
Effects of chop length (shorter: $6 \mathrm{~mm}$, or longer: 19 $\mathrm{mm}$ ) of alfalfa silage and oat silage were determined in 16 mid-lactation Holstein cows, 4 of which were rumen cannulated, using a replicated $4 \times 4$ Latin square design with a $2 \times 2$ arrangement of treatments. Experimental periods were $21 \mathrm{~d}$ long and consisted of $14 \mathrm{~d}$ of adaptation and $7 \mathrm{~d}$ of sampling. Cows received a total mixed ration containing [dry matter (DM) basis] $42.0 \%$ barley grain-based energy supplement, $10 \%$ protein supplement, and $24 \%$ of DM longer chop or shorter chop alfalfa silage and $24 \%$ of DM longer chop or shorter chop oat silage. Rumen $\mathrm{pH}$ was measured continuously, and rumen liquid flow rates were determined in rumen-cannulated cows. Feeding behavior was determined by videotaping, and meal patterns were determined by continuously weighing the feed in the bunk of 8 cows. Reducing the chop length of alfalfa silage and oat silage reduced the average geometric particle length from 14.2 to 10.9 $\mathrm{mm}$ and from 13.4 to $10.4 \mathrm{~mm}$, respectively. Reducing the alfalfa chop length did not affect feed intake, whereas reducing the oat silage chop length increased DM intake from to 19.4 to $21.2 \mathrm{~kg} / \mathrm{d}$. Reducing the chop lengths of alfalfa silage and oat silage chop length did not affect milk production, rumen fermentation, feeding behavior, meal patterns, and blood metabolites. Daily milk yield, milk fat percentage, and milk protein percentage averaged $36.1 \mathrm{~kg} / \mathrm{d}, 3.00 \%$, and $3.16 \%$, respectively, across diets. The low milk fat percentages suggest that the diets induced subacute ruminal acidosis. This was also substantiated by the rumen $\mathrm{pH}$, which was below 5.6 for more than $122 \mathrm{~min} / \mathrm{d}$ for all diets. The onset of subacute ruminal acidosis despite apparently adequate dietary neutral detergent fiber content and particle size distribution as well as the long duration of chewing might be attributed to sorting against long feed particles.
\end{abstract}

Received May 10, 2007.

Accepted February 2, 2008.

${ }^{1}$ Corresponding author: plaizier@ms.umanitoba.ca
Key words: forage chop length, feeding behavior, dairy cow, rumen $\mathrm{pH}$

\section{INTRODUCTION}

A recent survey demonstrated wide ranges in particle size distributions and particle lengths of legume silages and grain crop silages used on Manitoba dairy farms (Plaizier et al., 2004). Thirty-five percent of alfalfa silage samples and $30 \%$ of the corn silages samples collected in this survey conformed to the recommendations by Heinrichs and Kononoff (2002). Conversely, 35\% of alfalfa silage samples and $30 \%$ of corn silage samples had particle lengths that were shorter than these recommendations (Plaizier et al., 2004).

Silage particle lengths can affect the production and health of dairy cows, as long silage particle length can result in poor silage fermentation (Johnson et al., 2003), and shorter silage particle length can increase the risk of subacute ruminal acidosis (SARA; Mertens, 1997; Stone, 2004). Although considerable research has been conducted to explore the impact of feed particle length on rumen function and milk production, the results have been inconclusive. Several studies have shown that reducing the particle length of alfalfa silage, barley silage, and corn silage does not affect rumen $\mathrm{pH}$ (Kononoff and Heinrichs, 2003b; Yang and Beauchemin, 2006a), whereas others have demonstrated a reduction in rumen $\mathrm{pH}$ (Krause et al., 2002b; Beauchemin et al., 2003). Studies have also shown that reducing the forage particle length can increase DMI (Kononoff and Heinrichs, 2003a; Yang and Beauchemin, 2006a), have no affect on DMI (Beauchemin et al., 2003; Kononoff and Heinrichs, 2003b), or reduce DMI (Krause and Combs, 2003). Reducing the particle lengths of alfalfa silage and corn silage can lower milk fat (Kononoff and Heinrichs, 2003b; Krause and Combs, 2003). However, other studies did not observe this effect (Krause et al., 2002a; Beauchemin et al., 2003; Kononoff and Heinrichs, 2003a). The disparities among studies may be caused by interactions between numerous factors, including reduced forage particle size, grain source, forage source, 
forage to concentration ratio, range of particle lengths, and forage NDF content. Also, in most earlier studies, silage particle size was not altered by changing the chop length at harvesting, but by rechopping after ensiling. Hence, the effects of reducing silage chop length are difficult to predict from the results obtained in these studies. Many studies have been conducted on the effects of the particle lengths of alfalfa silage, corn silage, and barley silage (Krause and Combs, 2003; Yang and Beauchemin, 2006a,b; Bhandari et al., 2007), but very little information is available on the effects of the particle length of oat silage.

Bhandari et al. (2007) observed that reducing the chop length of alfalfa silage and corn silage from 19 to $10 \mathrm{~mm}$ and incorporating these silages in a barley grainbased TMR did not affect milk production. These authors also found that these reductions in chop length did not affect rumen $\mathrm{pH}$, but this finding was constrained by infrequent sampling of rumen fluid. The objectives of our study were to determine the effects of chop lengths of alfalfa silage and oat silage on feed intake, feeding, chewing behaviors, rumen fermentation, milk production, and blood parameters in lactating dairy cows fed an alfalfa silage, oat silage, and barley grain-based TMR.

\section{MATERIALS AND METHODS}

\section{Experimental Procedures}

Sixteen multiparous lactating Holstein cows, housed in a tie-stall barn at the Glenlea Research Station, University of Manitoba, were used in a replicated $4 \times 4$ Latin square design with a $2 \times 2$ arrangement of treatments. The experimental design was balanced for the residual effects. Feeding behavior and water intake were determined for the rumen-cannulated cows, which composed one square, as well as for the cows of another square. Each experimental period consisted of a 14-d adaptation period, followed by a 7-d collection period. Animals were cared for in accordance with the Canadian Council for Animal Care guidelines (CCAC, 1993). Upon commencement of the experiment, cows were on average $64.9 \pm 25.9 \mathrm{~d}$ in milk (mean $\pm \mathrm{SD}$ ), with an average BCS of $3.09 \pm 0.25$ on a 5 -point scale (Edmonson et al., 1989) and an average BW of $611 \pm 78 \mathrm{~kg}$.

Second-cut alfalfa (Pickseed Custom Forage Mix, Pickseed Canada Inc., Winnipeg, MB, Canada) was harvested in the late bud stage. Oats (Ronald, SeCan, Kanata, ON, Canada) were harvested in the milk stage. Oats and alfalfa that were grown on the same field were chopped to either $6 \mathrm{~mm}$ (shorter chop) or $19 \mathrm{~mm}$ (longer chop) using a New Holland Forage Harvester, model 790 (New Holland Inc., New Holland, PA). Both the 19$\mathrm{mm}$ and 6-mm chop lengths were harvested on the same day for each crop. Alfalfa silage and oat silage were ensiled and stored in plastic-covered piles of approximately 30 tons without additives or inoculants for 3 mo and 1 mo before the beginning of the experiment, respectively.

Cows were assigned to 1 of 4 diets during each of the 4 experimental periods (Table 1 ). Diets were fed as TMR and contained (DM basis) $42.0 \%$ barley grain-based energy supplement (containing $42 \%$ pellets) and $10.0 \%$ protein supplement (containing 58\% pellets; Table 1 and 2), $24 \%$ of either longer or shorter chop of alfalfa and $24 \%$ of either longer or shorter chop of oat silage. The concentrate to forage ratio was $52: 48$ on a DM basis. Diets were mixed using a Data Ranger mixer (American Calan, Northwood, NH) with a Weigh Tronix weigh head (model 1000, American Calan). The TMR were fed once daily for ad libitum consumption allowing 5 to $10 \%$ orts. Cows had unlimited access to water.

\section{DMI and Feed Analyses}

During the collection periods, the amounts of TMR offered and refused were recorded daily for each cow. Diet samples and individual ort samples were collected daily. Diet samples were collected daily and pooled for each collection period. Individual cow ort samples were obtained daily during the collection periods and pooled by period by mixing equal proportions of the daily orts. Forages samples were collected once per collection period. The DM content of pooled diet samples, pooled orts samples, and forage samples were determined by drying at $60^{\circ} \mathrm{C}$ for $48 \mathrm{~h}$. Dried feed samples were ground using a Wiley mill through a 1-mm screen (ThomasWiley, Philadelphia, PA) and stored at $-20^{\circ} \mathrm{C}$ until analyzed. Before subsequent analysis, analytical DM was determined (method 934.01; AOAC, 1990). All feed samples were analyzed for $\mathrm{CP}$ using the $\mathrm{CuSO}_{4} / \mathrm{TiO}_{2}$ mixed catalyst Kjeldahl procedure (method 988.05; AOAC, 1990), for NDF using $\alpha$-amylase (Van Soest et al., 1991; A3306, Sigma Chemical Co., St. Louis, MO), for sodium sulfite and corrected for ash concentration adapted for Ankom 200 Fiber Analyzer (Ankom Technology, Fairport, NY), for ADF (method 973.18; AOAC, 1990), for ether extract (method 920.39; AOAC, 1990), and for ash (method 942.05; AOAC, 1990). Calcium, P, K, Mg, and Na were measured by inductively coupled plasma emission spectrometry (method 968.08; AOAC, 1990) using an Atom Scan 25 plasma spectrometer (Thermo Jarrell Ash Corp., Grand Junction, CO) after acid digestion.

Particle size distributions were determined for all TMR, pooled refusals per animal per period, and forage samples using the Penn State Particle Separator (PSPS; Kononoff et al., 2003). Approximately $150 \mathrm{~g}$ of wet sample was placed on the top screen of the PSPS. 
Table 1. Ingredients and nutrient composition of experimental diets containing shorter (6 mm) or longer (19 $\mathrm{mm})$ chop lengths of alfalfa and oat silages

\begin{tabular}{|c|c|c|c|c|c|c|c|c|}
\hline \multirow{2}{*}{$\begin{array}{l}\text { Diet ingredients, } \\
\% \text { of DM }\end{array}$} & \multicolumn{4}{|c|}{ Diet $^{1}$} & \multirow[b]{2}{*}{$\mathrm{SE}$} & \multicolumn{3}{|c|}{ Effect $^{2}$} \\
\hline & ALOL & ALOS & ASOL & ASOS & & $\mathrm{AC}$ & $\mathrm{OC}$ & $\mathrm{AC} \times \mathrm{OC}$ \\
\hline Shorter chop alfalfa silage & - & - & 24 & 24 & & & & \\
\hline Longer chop alfalfa silage & 24 & 24 & - & - & & & & \\
\hline Shorter chop oat silage & - & 24 & - & 24 & & & & \\
\hline Longer chop oat silage & 24 & - & 24 & - & & & & \\
\hline Energy supplement & 42 & 42 & 42 & 42 & & & & \\
\hline Protein supplement & 10 & 10 & 10 & 10 & & & & \\
\hline \multicolumn{9}{|l|}{ Nutrient composition $^{2}$} \\
\hline $\mathrm{DM}, \%$ & 46.3 & 48.1 & 46.9 & 49.8 & 0.46 & 0.09 & $<0.05$ & 0.44 \\
\hline $\mathrm{CP}, \%$ of $\mathrm{DM}$ & 15.8 & 15.4 & 15.5 & 16.7 & 0.17 & 0.06 & 0.09 & 0.21 \\
\hline $\mathrm{ADIP},{ }^{3} \%$ of $\mathrm{DM}$ & 1.4 & 2.3 & 2.3 & 2.4 & 0.27 & 0.23 & 0.38 & 0.38 \\
\hline $\mathrm{NDF}, \%$ of DM & 38.7 & 38.3 & 38.5 & 37.9 & 0.93 & 0.57 & 0.71 & 0.90 \\
\hline $\mathrm{ADF}, \%$ of $\mathrm{DM}$ & 27.2 & 30.3 & 28.1 & 26.1 & 0.74 & 0.13 & 0.60 & 0.09 \\
\hline Ether extract, \% of DM & 3.0 & 3.6 & 3.4 & 3.7 & 0.20 & 0.74 & 0.51 & 0.54 \\
\hline Ash, $\%$ of DM & 10.7 & 10.2 & 10.5 & 11.5 & 0.32 & 0.85 & 0.91 & 0.84 \\
\hline $\mathrm{NFC},{ }^{4} \%$ of DM & 31.8 & 32.5 & 32.1 & 30.2 & 1.03 & 0.74 & 0.51 & 0.54 \\
\hline $\mathrm{Ca}, \%$ of $\mathrm{DM}$ & 1.20 & 1.11 & 1.05 & 1.08 & 0.04 & 0.10 & 0.54 & 0.27 \\
\hline $\mathrm{P}, \%$ of $\mathrm{DM}$ & 0.49 & 0.43 & 0.49 & 0.53 & 0.02 & 0.07 & 0.08 & 0.09 \\
\hline $\mathrm{K}, \%$ of $\mathrm{DM}$ & 2.22 & 2.33 & 2.19 & 2.15 & 0.09 & 0.38 & 0.76 & 0.55 \\
\hline $\mathrm{Mg}, \%$ of $\mathrm{DM}$ & 0.39 & 0.38 & 0.36 & 0.37 & 0.01 & 0.27 & 0.85 & 0.35 \\
\hline $\mathrm{Na}, \%$ of $\mathrm{DM}$ & 0.49 & 0.43 & 0.46 & 0.50 & 0.02 & 0.56 & 0.71 & 0.14 \\
\hline
\end{tabular}

${ }^{1} \mathrm{ALOL}=$ alfalfa longer chop and oat longer chop; ALOS = alfalfa longer chop and oat shorter chop; ASOL = alfalfa shorter chop and oat longer chop; ASOS = alfalfa short chop and oat short chop.

${ }^{2}$ Nutrient compositions of experimental diets were measured for each experimental period $(\mathrm{n}=4)$. $\mathrm{AC}=$ alfalfa chop effect; $\mathrm{OC}=$ oat chop effect; $\mathrm{AC} \times \mathrm{OC}=$ interaction effect of alfalfa and oat chop lengths.

${ }^{3} \mathrm{ADIP}=$ acid detergent insoluble protein.

${ }^{4} \mathrm{NFC}$ calculated as $100-\% \mathrm{CP}-\% \mathrm{NDF}-\%$ ether extract - \% ash.

The PSPS was shaken 40 times (5 times in each direction, twice; Kononoff et al., 2003). The contents of each fraction were weighed and analyzed for DM and NDF

Table 2. Ingredient composition of energy supplement and protein supplement (\% of DM)

\begin{tabular}{lcc}
\hline Ingredient & $\begin{array}{c}\text { Energy } \\
\text { supplement }\end{array}$ & $\begin{array}{c}\text { Protein } \\
\text { supplement }\end{array}$ \\
\hline Rolled barley & 54.0 & - \\
Luprosil salt (calcium propionate) $^{1}$ & 0.2 & - \\
Protein pellet $^{1}$ & 1.8 & - \\
Dairy supplement $^{2}$ & 40.0 & - \\
Vegetable oil $_{\text {Dried distillers grain }}$ & 4.0 & 42.0 \\
Fish meal & - & 7.0 \\
Canola meal & - & 22.7 \\
Soybean meal & - & 20.0 \\
Beet molasses & - & 3.0 \\
Niacin & - & 0.3 \\
Sodium bicarbonate & - & 5.0 \\
\hline
\end{tabular}

${ }^{1}$ Protein pellets contain (DM basis) $46.1 \%$ soybean meal, $2.6 \%$ wheat shorts, $40.0 \%$ canola meal, $5.0 \%$ oat hulls, $0.3 \%$ pellet binder, $1.0 \%$ cane molasses, and $5.0 \%$ corn gluten meal.

${ }^{2}$ Dairy supplement contains (DM basis) $0.13 \%$ vitamin $\mathrm{A}, \mathrm{D}$, and E premix (vitamin A, 16,800 IU/kg; vitamin D, 2,215 IU/kg; vitamin E, $75 \mathrm{IU} / \mathrm{kg}$, DM basis), $0.13 \%$ trace mineral premix, $2.6 \%$ soybean meal, $0.06 \%$ selenium, $39.1 \%$ wheat shorts, $5.0 \%$ distillers grain, $17.5 \%$ canola meal, $15.0 \%$ ground wheat, $1.7 \%$ dicalcium phosphate, $1.6 \%$ salt, $2.0 \%$ dynamate, $0.3 \%$ pellet binder, $1.0 \%$ cane molasses, $3.7 \%$ calcium carbonate, and $10.0 \%$ corn gluten meal. as described earlier. Physically effective fiber was determined using 3 techniques: 1) as the proportion of the dietary NDF retained by the PSPS sieves ( $\mathbf{p e N D F}_{\mathbf{N D F}}$ ); 2 ) as the proportion of dietary DM retained by the PSPS sieves multiplied by the dietary NDF content

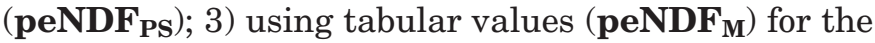
physical effectiveness of feeds as recommended by Mertens (1997). The geometric mean and standard deviation of feed samples were obtained by fitting PSPS distribution with a lognormal equation, as described by Kononoff et al. (2003). Sorting was calculated as described by Leonardi and Armentano (2003) and Leonardi et al. (2005) as the actual intake of each PSPS fraction expressed as a percentage of the predicted intake of this PSPS fraction. Values lower than 100\% indicate selective refusals, values greater than $100 \%$ indicate preferential consumption, and a value of $100 \%$ indicates the absence of sorting.

Particle size distributions of TMR were also measured by dry sieving using a vertical oscillating test sieve shaker (EFL 1 KII, Endecotts Ltd., London, UK) equipped with a stack of 6 brass sieves and a bottom pan with a 200-mm diameter (ASTM E11, Endecotts Ltd.) arranged in descending mesh size. Sieve mesh sizes were 19, 9.5, 6.3, 4.0, 1.18, and $0.6 \mathrm{~mm}$. Approximately $200 \mathrm{~g}$ was placed on the top screen, and the 
stack of sieves was shaken until the distribution of materials did not change (approximately $15 \mathrm{~min}$ ). The peNDF $_{>1.18}$ was determined as the proportion of DM retained on and above the $1.18-\mathrm{mm}$ screen multiplied by dietary NDF.

Alfalfa silage and corn silage were analyzed for VFA, lactate, and ethanol using HPLC as described by Bhandari et al. (2007). Forage $\mathrm{pH}$ was also measured as described by Bhandari et al. (2007). Ammonia nitrogen concentration of silage samples was determined according to AOAC method 920.03 (AOAC, 1990).

\section{Eating Behavior and Meal Sizes}

Eight cows from 2 Latin squares were videotaped for 3 consecutive days during each sample period using 4 low-light level black and white video cameras (WV-BP 134 Panasonic), a multiplexer (WJ-FS 216 Digital Panasonic), and a time-lapse video recorder (Panasonic AG $6720 \mathrm{~A})$. The 4 cameras were placed about $5 \mathrm{~m}$ above the floor to allow complete visualization of the 2 pens. Cameras were linked to a central monitor and video recorder. Barn lights were turned off between 2200 and $0330 \mathrm{~h}$. Video recording at night was conducted with seven $40-\mathrm{W}$ red bulbs, providing a total light intensity of less than $3 \mathrm{~lx}$. Eating and ruminating activities were determined by instantaneous scan sampling at 5 -min intervals (Maekawa et al., 2002; Leonardi et al., 2005; Rotger et al., 2006). All other activities of the animals excluding the eating and ruminating activities were assigned as idle. These activities were recorded for 1 min after every $5 \mathrm{~min}$ and it was assumed that each activity persisted for the entire 5-min interval (Maekawa et al., 2002; Leonardi et al., 2005; Rotger et al., 2006). Total time spent chewing was calculated as the sum of eating and ruminating time. A pilot study showed that the collection coefficient between continuous monitoring and 5-min scan sampling of feeding and ruminating activities was 0.92 (S. K. Bhandari; unpublished data). This correlation coefficient compared well with that of 0.94 between continuous monitoring of feeding activities and scan sampling of feeding behavior of feedlot cattle using a 5-min interval reported by Mitlöhner et al. (2001).

Feed intakes of all cows were monitored continuously during each sampling period. Bunks were cleaned daily before the next feed allocation. Each feed bunk was connected to a weight acquisition system (model 4000/ E, Growsafe Systems Ltd., Airdrie, AB, Canada) consisting of $400-\mathrm{kg}$ load cell bars connected to an A/D converter. The output signals were recorded in a computer using the appropriate software (model 4000 data acquisition software, version 1.2 MOD, Growsafe Systems Ltd.). Meals were defined as the combination of eating activities that were separated by intervals shorter than or equal to the meal criterion (Tolkamp and Kyriazakis, 1999; Tolkamp et al., 2000). Meal criteria were determined by fitting the log transformed intervals between eating events to 3 Gaussian distributions and determining the interval length where the 2 Gaussian distributions with the largest means intersected, as described by Tolkamp and Kyriazakis (1999) and Tolkamp et al. (2000). The maximum likelihood procedure of GENSTAT version 9.1 (VSN International Ltd., Hemel Hempstead, UK) was used for curve fitting. Meal criteria were calculated separately for each cow for on each diet. Subsequently, the duration, size, and eating rate were determined for each meal.

\section{Rumen pH and Rumen Liquid Flow Rate Measurement}

Rumen $\mathrm{pH}$ was measured continuously in the rumen cannulated cows from Monday at $0900 \mathrm{~h}$ to Saturday at $0900 \mathrm{~h}$ during each sampling period using indwelling $\mathrm{pH}$ probes as described by Gozho et al. (2005). Rumen $\mathrm{pH}$ was measured at 1-min intervals and data sent to a data logger for storage and used for subsequent analysis. Rumen $\mathrm{pH}$ data were summarized by calculating the average $\mathrm{pH}$, the time below $\mathrm{pH} 6$, the time below $\mathrm{pH} 5.6$, the area (time $\times \mathrm{pH}$ ) below $\mathrm{pH} 6$, and the area below $\mathrm{pH} 5.6$ for each 24-h period, as described by Gozho et al. (2005).

Rumen fluid from all cows was collected at 4 to $5 \mathrm{~h}$ after the delivery of fresh feed on $2 \mathrm{~d}$ during each sampling period. Rumen fluid was obtained from nonfistulated cows using a Geishauser oral probe (Duffield et al., 2004). The first $200 \mathrm{~mL}$ of collected rumen fluid was discarded and the subsequent $50 \mathrm{~mL}$ of rumen fluid was kept for subsequent analysis and processing (Duffield et al., 2004). Rumen fluid from the fistulated cows was obtained from the cranial ventral region. Rumen fluid samples were centrifuged immediately after collection at $1,900 \times \mathrm{g}$ for $10 \mathrm{~min}$ and the supernatant stored at $-20^{\circ} \mathrm{C}$ until further analysis.

The rumen liquid outflow rate was measured using Cr-EDTA in the 4 rumen-cannulated cows. The method used to prepare the Cr-EDTA was that of Uden et al. (1980). A solution of Cr-EDTA in distilled water was introduced into several sites in the rumen through the ruminal cannula at $0900 \mathrm{~h}$. Ruminal fluid samples were collected at $0,2,4,6,8,12,16,24,48$, and $72 \mathrm{~h}$ postdosing from the ventral sac of the rumen. Rumen fluid samples were analyzed for the $\mathrm{Cr}$ concentration using the inductive coupled plasma optical emission spectroscopy (ICP-OES; Vista MPX, Varian, Walnut Creek, CA) and the liquid rate of passage from the rumen was 
estimated as the slope of the regression of the natural logarithm of the concentration with time postdosing.

\section{Blood Sampling and Analysis}

Blood samples were collected at 4 to $5 \mathrm{~h}$ postfeeding on $2 \mathrm{~d}$ during each sampling period by coccygeal venipuncture in heparinized 10-mL Vacutainers. Samples were subsequently centrifuged at $1,900 \times g$ for $10 \mathrm{~min}$ and the plasma was aspirated and stored at $-20^{\circ} \mathrm{C}$ until further analysis. Blood plasma was analyzed for glucose, urea, and lactate using a Nova Stat Profile M blood gas and electrolyte analyzer (Nova Biomedical Corporation, Waltham, MA) as described by Bhandari et al. (2007).

\section{VFA, Ammonia, and Rumen Fluid Marker Analysis}

Frozen rumen fluid samples were thawed at room temperature and $1 \mathrm{~mL}$ of $25 \%$ meta-phosphoric acid solution was added to $5 \mathrm{~mL}$ of rumen fluid. The tubes were vortexed and placed in a $-20^{\circ} \mathrm{C}$ freezer for $17 \mathrm{~h}$. Thawed samples were centrifuged for $10 \mathrm{~min}$ at 1,900 $\times$ g. Approximately $2 \mathrm{~mL}$ of supernatant was decanted into a clean, dry vial. The samples were capped and placed into the autosampler device (model 8100, Varian) for analysis. Concentrations of VFA were determined by gas chromatography as described by Bhandari et al. (2007). Ammonia nitrogen concentration of rumen fluid samples was determined as described by Bhandari et al. (2007).

\section{Milk Yield and Composition Analysis}

Cows were milked twice daily in their stalls and milk production was measured using Tru-Test regulation meters (Westfalia Surge, Mississauga, ON, Canada) that were accurate within $5 \%$ or $0.3 \mathrm{~L}$. Milk samples were collected from 4 consecutive milkings in $50-\mathrm{mL}$ vials in each collection period and preserved with 2 bromo-2-nitropropane-1,3 diol. Milk samples were stored at $4^{\circ} \mathrm{C}$ until analyzed for fat and protein at the laboratory of the Dairy Farmers of Manitoba (Winnipeg, MB, Canada) by near infrared analysis using the MilkoScan 303AB (Foss Electric, Hillerød, Denmark). This infrared analysis was calibrated by the Babcock method for milk fat analysis (method 989.04; AOAC, 1990) and the Kjeldahl method for nitrogen/protein nitrogen analysis in milk (method 991.22; AOAC, 1990).

\section{Statistical Analysis}

An ANOVA of data on rumen fluid composition, blood plasma variables, milk production, feed intakes, feed- ing behavior variables, and sorting was conducted using MIXED procedure (SAS Institute, 1990). The effects of alfalfa chop length and corn chop length and their interaction were considered fixed. The effects of square, cow within square, period, and day within period were considered random. Day within period was considered a repeated measure. An ANOVA of weekly averages of chemical and physical characteristics of experimental diets was also conducted with the MIXED procedure (SAS Institute, 1990), considering the effects of alfalfa chop length and corn chop length and their interaction as fixed effects.

An ANOVA of the proportion of the daily DMI consumed within 3-h periods relative to feed delivery was conducted using the MIXED procedure (SAS Institute, 1990) as recommended by Wang and Goonewardene (2004) for the analysis of animal experiments with repeated measures. The effects of alfalfa chop length and corn chop length and their interaction were considered fixed, and cow within square was considered as the experimental unit.

Data on meal sizes, meal durations and eating rates were log transformed before statistical analysis. Statistical significance was set at $P \leq 0.05$; trends were discussed at $P \leq 0.10$. Differences among treatment means were tested for significance using Tukey's multiple range test (SAS Institute, 1990). Reported standard errors are those used for the comparison of treatment means. The 95\% confidence intervals least squares treatment means of sorting were calculated to determine if these means differed significantly from $100 \%$.

Rumen liquid outflow rate was measured using the marker Cr-EDTA and was estimated using the following formula:

$$
\mathrm{C}(\mathrm{t})=\mathrm{C}_{0} \mathrm{e}^{-\mathrm{kt}} \text {, }
$$

where $\mathrm{C}(\mathrm{t})=$ marker concentration in rumen at time $\mathrm{t}$; $\mathrm{C}_{0}=$ marker concentration in rumen at time of infusion $(\mathrm{t}=0$ ); and $\mathrm{k}=$ rumen liquid outflow rate (outflow/ volume) per time unit.

\section{RESULTS}

\section{Chemical and Physical Compositions of Forages and Diets}

The chemical and physical compositions of the experimental forages are given in Tables 3 and 4, respectively. Table 3 shows the shorter chop of both forages resulted in lower silage $\mathrm{pH}$ and greater silage VFA than the longer chop of these silages. The other nutrients that were measured were similar for both chop lengths of these silages. Reducing the chop length of alfalfa silage and oat silage from 19 to $6 \mathrm{~mm}$ reduced the proportion 
Table 3. Nutrient composition and silage fermentation profile $( \pm \mathrm{SD})$ of the silages included in the experimental diets

\begin{tabular}{lrrrr}
\hline & \multicolumn{5}{c}{ Silage $^{1}$} \\
\cline { 2 - 5 } Item & \multicolumn{1}{c}{ AL } & AS & OL & OS \\
\hline Nutrient composition $^{2}$ & & & & \\
DM, \% & $42.1(1.4)$ & $40.3(2.7)$ & $29.6(0.7)$ & $30.0(1.9)$ \\
CP, \% of DM & $16.9(0.9)$ & $17.3(0.2)$ & $10.5(0.5)$ & $11.1(0.8)$ \\
NDF, \% of DM & $48.4(2.2)$ & $48.0(0.8)$ & $59.4(1.9)$ & $59.9(4.2)$ \\
ADIP, \% of DM & $1.7(0.1)$ & $1.4(0.1)$ & $1.0(0.1)$ & $0.8(0.1)$ \\
ADF, \% of DM & $34.8(2.2)$ & $33.8(1.7)$ & $36.8(1.5)$ & $36.0(1.2)$ \\
Ether extract, \% of DM & $2.0(0.3)$ & $2.0(0.3)$ & $3.2(0.1)$ & $3.1(0.1)$ \\
Ash, \% of DM & $11.3(0.3)$ & $13.1(0.3)$ & $9.3(0.2)$ & $9.7(0.2)$ \\
NFC, \% of DM & & & & \\
Ca, \% of DM & $1.30(0.06)$ & $1.37(0.16)$ & $0.41(0.22)$ & $0.41(0.19)$ \\
P, \% of DM & $0.27(0.02)$ & $0.29(0.02)$ & $0.33(0.04)$ & $0.36(0.02)$ \\
K, \% of DM & $3.00(0.23)$ & $3.13(0.28)$ & $2.05(0.27)$ & $2.41(0.27)$ \\
Mg, \% of DM & $0.39(0.03)$ & $0.41(0.04)$ & $0.26(0.08)$ & $0.26(0.03)$ \\
Na, \% of DM & $0.05(0.01)$ & $0.04(0.00)$ & $0.29(0.07)$ & $0.32(0.03)$ \\
Fermentation profile ${ }^{5}$ & & & & \\
pH & $6.0(1.5)$ & $4.9(0.4)$ & $5.4(1.3)$ & $4.6(0.2)$ \\
VFA (\% of DM) & $4.7(1.8)$ & $5.3(0.7)$ & $3.1(1.9)$ & $4.4(0.3)$ \\
Lactic acid (\% of DM) & $2.3(1.9)$ & $3.9(0.8)$ & $0.8(0.5)$ & $1.3(1.0)$ \\
Ammonia (\% of CP) & $18.2(6.9)$ & $14.2(6.2)$ & $13.2(2.5)$ & $17.3(1.2)$ \\
\hline
\end{tabular}

${ }^{1} \mathrm{AL}=$ alfalfa longer chop $(19 \mathrm{~mm}) ; \mathrm{AS}=$ alfalfa shorter chop $(6 \mathrm{~mm}) ; \mathrm{OL}=$ oat longer chop $(19 \mathrm{~mm}) ; \mathrm{OS}=$ oat shorter chop (6 mm).

${ }^{2}$ Nutrient composition of forages were determined for each experimental period $(n=4)$.

${ }^{3} \mathrm{ADIP}=$ acid detergent insoluble protein

${ }^{4} \mathrm{NFC}$ calculated as $100-\% \mathrm{CP}-\% \mathrm{NDF}-\%$ ether extract $-\%$ ash.

${ }^{5}$ Fermentation profile of the forages were determined for each experimental period $(n=4)$.

of silage retained by the $19-\mathrm{mm}$ screen of the PSPS from 39.2 to $20.6 \%$ of $\mathrm{DM}$ and from 25.7 to $12.2 \%$ of DM, respectively (Table 4 ). The reduction in forage chop length increased the proportions of silage retained by the 8-mm screen of the PSPS from 44.3 to $54.7 \%$ of DM and from 56.1 to $62.6 \%$ of DM, respectively. Reducing the chop length of alfalfa silage and oat silage at harvest from 19 to $6 \mathrm{~mm}$ reduced the actual average particle

Table 4. Penn State particle size analysis, geometric mean $\left(\mathrm{X}_{\mathrm{gm}}\right)$, and standard deviation $\left(\mathrm{S}_{\mathrm{gm}}\right)( \pm \mathrm{SD})$ of shorter $(6 \mathrm{~mm})$ or longer $(19 \mathrm{~mm})$ chop lengths of alfalfa and oat silages

\begin{tabular}{|c|c|c|c|c|}
\hline \multirow[b]{2}{*}{ PSPS distribution $^{2}$} & \multicolumn{4}{|c|}{ Silage $^{1}$} \\
\hline & $\mathrm{AL}$ & AS & $\mathrm{OL}$ & OS \\
\hline \multicolumn{5}{|c|}{ Percent retained, as-fed basis } \\
\hline Top screen $(19 \mathrm{~mm})$ & $39.3(7.1)$ & $20.6(2.7)$ & $29.4(5.6)$ & $13.3(2.5)$ \\
\hline Second screen $(8 \mathrm{~mm})$ & $45.1(3.9)$ & $55.5(2.7)$ & $56.1(3.1)$ & $63.0(4.0)$ \\
\hline Third screen (1.18 mm) & $14.2(3.9)$ & $22.5(4.1)$ & $13.9(5.1)$ & $23.1(5.7)$ \\
\hline Bottom pan & $1.4(0.3)$ & $1.4(0.7)$ & $0.6(0.8)$ & $0.6(0.7)$ \\
\hline \multicolumn{5}{|l|}{ Percent retained, DM basis } \\
\hline Top screen $(19$ mm) & $39.2(7.0)$ & $20.6(2.7)$ & $25.7(5.6)$ & $12.2(2.9)$ \\
\hline Second screen (8 mm) & $44.3(3.2)$ & $54.7(2.7)$ & $56.1(3.1)$ & $62.6(4.1)$ \\
\hline Third screen $(1.18 \mathrm{~mm})$ & $14.4(4.0)$ & $23.0(4.0)$ & $17.0(5.8)$ & $24.2(5.8)$ \\
\hline Bottom pan & $2.2(0.4)$ & $1.8(1.0)$ & $1.8(1.4)$ & $1.1(1.2)$ \\
\hline \multicolumn{5}{|l|}{ As-fed basis ${ }^{3}$} \\
\hline $\mathrm{X}_{\mathrm{gm}}, \mathrm{mm}$ & $14.2(1.6)$ & $10.9(1.0)$ & $13.4(1.6)$ & $10.4(1.1)$ \\
\hline $\mathrm{S}_{\mathrm{gm}}, \mathrm{mm}$ & $2.2(0.1)$ & $2.1(0.1)$ & $2.0(0.1)$ & $2.0(0.1)$ \\
\hline
\end{tabular}

${ }^{1} \mathrm{AL}=$ alfalfa longer chop $(19 \mathrm{~mm}) ; \mathrm{AS}=$ alfalfa shorter chop $(6 \mathrm{~mm}) ; \mathrm{OL}=$ oat longer chop $(19 \mathrm{~mm}) ; \mathrm{OS}=$ oat shorter chop (6 mm).

${ }^{2}$ Penn State Particle Separator (PSPS) distributions of experimental silages were calculated for each period $(n=4)$ for each treatment.

${ }^{3} \mathrm{X}_{\mathrm{gm}}=$ geometric mean length, calculated on an as-fed basis (Kononoff and Heinrichs, 2002); $\mathrm{S}_{\mathrm{gm}}=$ standard deviation, calculated on an as-fed basis (Kononoff and Heinrichs, 2002). 
Table 5. Penn State Particle Separator analysis, physical effective fiber content, geometric mean $\left(\mathrm{X}_{\mathrm{gm}}\right)$, and standard deviation $\left(\mathrm{S}_{\mathrm{gm}}\right)$ and sorting of experimental diets containing a shorter $(6 \mathrm{~mm})$ or longer $(19 \mathrm{~mm})$ chop lengths of alfalfa and oat silages

\begin{tabular}{|c|c|c|c|c|c|c|c|c|}
\hline \multirow[b]{2}{*}{ Item } & \multicolumn{4}{|c|}{$\operatorname{Diet}^{1}$} & \multirow[b]{2}{*}{ SE } & \multicolumn{3}{|c|}{ Effect $^{2}$} \\
\hline & ALOL & ALOS & ASOL & ASOS & & $\mathrm{AC}$ & $\mathrm{OC}$ & $\mathrm{AC} \times \mathrm{OC}$ \\
\hline \multicolumn{9}{|c|}{ Percent retained, as-fed basis } \\
\hline Top screen $(19 \mathrm{~mm})$ & 23.1 & 17.3 & 16.4 & 10.0 & 2.15 & $<0.01$ & $<0.05$ & 0.90 \\
\hline Second screen (8 mm) & 52.5 & 52.7 & 56.2 & 56.4 & 1.22 & $<0.05$ & 0.82 & 0.98 \\
\hline Third screen $(1.18 \mathrm{~mm})$ & 22.2 & 27.5 & 25.0 & 30.6 & 2.34 & 0.22 & $<0.05$ & 0.95 \\
\hline Bottom pan & 2.2 & 2.5 & 2.4 & 3.0 & 0.30 & 0.13 & 0.30 & 0.59 \\
\hline \multicolumn{9}{|l|}{ Percent retained, DM basis } \\
\hline Top screen $(19 \mathrm{~mm})$ & 18.5 & 14.5 & 12.8 & 7.9 & 1.83 & $<0.01$ & $<0.05$ & 0.81 \\
\hline Second screen $(8 \mathrm{~mm})$ & 52.9 & 54.4 & 56.5 & 56.7 & 2.49 & 0.05 & 0.56 & 0.63 \\
\hline Third screen $(1.18 \mathrm{~mm})$ & 25.7 & 28.2 & 27.6 & 31.8 & 1.78 & 0.29 & 0.21 & 0.75 \\
\hline Bottom pan & 2.9 & 3.0 & 3.2 & 3.8 & 0.51 & 0.20 & 0.37 & 0.48 \\
\hline \multicolumn{9}{|c|}{ NDF retained in fraction, \% of DM } \\
\hline Top screen $(19 \mathrm{~mm})$ & 53.9 & 51.5 & 54.7 & 56.3 & 0.81 & $<0.01$ & 0.62 & 0.12 \\
\hline Second screen $(8 \mathrm{~mm})$ & 34.4 & 36.9 & 34.2 & 35.1 & 0.96 & 0.31 & 0.09 & 0.42 \\
\hline Third screen $(1.18 \mathrm{~mm})$ & 29.3 & 32.2 & 30.0 & 33.6 & 0.67 & 0.16 & $<0.001$ & 0.61 \\
\hline Bottom pan & 34.6 & 36.0 & 35.7 & 35.5 & 0.64 & 0.62 & 0.33 & 0.25 \\
\hline \multicolumn{9}{|c|}{ Physical effective fiber and particle length } \\
\hline $\mathrm{peNDF}_{\mathrm{NDF}},{ }^{4} \%$ of DM & 28.1 & $\begin{array}{l}20.4 \\
27.5\end{array}$ & 26.3 & 24.3 & 1.47 & 0.11 & 0.41 & $\begin{array}{l}0.48 \\
0.65\end{array}$ \\
\hline peNDF $_{>1.18},{ }^{5} \mathrm{~mm}$ & 30.2 & 29.9 & 30.2 & 27.9 & 1.16 & 0.35 & 0.24 & 0.37 \\
\hline $\mathrm{X}_{\mathrm{gm}},{ }_{7}^{6} \mathrm{~mm}$ & 10.9 & 9.7 & 9.9 & 8.6 & 0.45 & $<0.05$ & $<0.05$ & 0.95 \\
\hline $\mathrm{S}_{\mathrm{gm}},{ }^{\mathrm{min}} \mathrm{mm}$ & 2.2 & 2.2 & 2.2 & 2.2 & 0.03 & 0.13 & 0.90 & 0.90 \\
\hline
\end{tabular}

${ }^{1} \mathrm{ALOL}=$ alfalfa longer chop and oat longer chop; ALOS = alfalfa longer chop and oat shorter chop; ASOL = alfalfa short chop and oat longer chop; ASOS = alfalfa short chop and oat short chop.

${ }^{2}$ Penn State Particle Separator distributions of experimental diets were calculated for each period $(\mathrm{n}=$ 4) for each treatment. $\mathrm{AC}=$ alfalfa chop effect; $\mathrm{OC}=$ oat chop effect; $\mathrm{AC} \times \mathrm{OC}=$ interaction effect of alfalfa and oat chop lengths.

${ }^{3}$ peNDF $_{\mathrm{PS}}=$ proportion of DM retained by the 19- and 8-mm PSPS screens multiplied by dietary NDF content.

${ }^{4} \mathrm{peNDF}_{\mathrm{NDF}}=$ proportion of NDF retained by the 19- and 8-mm PSPS screens.

${ }^{5} \mathrm{peNDF}_{>1.18 \mathrm{~mm}}=$ proportion of NDF retained by $\geq 1.18$-mm screens.

${ }^{6} \mathrm{X}_{\mathrm{gm}}=$ geometric mean length, calculated on an as-fed basis (Kononoff and Heinrichs, 2002).

${ }^{7} \mathrm{~S}_{\mathrm{gm}}=$ standard deviation, calculated on an as-fed basis (Kononoff and Heinrichs, 2002).

length from 14.4 to $10.0 \mathrm{~mm}$, and from 13.4 to 10.4 $\mathrm{mm}$, respectively.

The chemical and physical compositions of the experimental diets are given in Tables 1 and 5, respectively. Table 1 shows that DM was greater and that the CP tended to be greater in the diets containing the shorter chop oat silage compared with the diets containing the longer chop oat silage. Diets did not differ in the other nutrients that were measured. Reducing the chop length of both silages reduced the proportion of the diet retained by the 19-mm PSPS screen from 18.5 to $7.9 \%$ of DM. It also increased the proportion of the diet retained by the 8-mm PSPS screen from 52.9 to 56.7 of $\mathrm{DM}$, and reduced the average particle length from 10.9 to $8.6 \mathrm{~mm}$ (Table 5). For all diets, the NDF contents of the fractions retained by the 19- and 8-mm PSPS screens were greater than those of the fractions retained by the 1.18-mm screen and the bottom pan. As a result, values for peNDF $\mathrm{NDF}_{\mathrm{N}}$ were greater than those for $\mathrm{pNDF}_{\mathrm{PS}}$. Values for peNDF $>1.18 \mathrm{~mm}$ were greater than those for peNDF $F_{\mathrm{NDF}}$ and peNDF $\mathrm{PS}_{\text {. Despite an }}$ effect of alfalfa silage chop length and oats silage chop length on the geometric mean of the feed particle length, both chop lengths did not significantly affect peNDF ${ }_{\mathrm{PS}}$, peNDF $_{\mathrm{NDF}}$, or peNDF $>1.18$.

\section{Feed and Water Intake and Feeding Behavior}

Reducing the chop length of alfalfa did not affect DMI, but reducing the chop length of oats increased DMI from 19.4 to $21.2 \mathrm{~kg} / \mathrm{d}$ across alfalfa chop lengths (Table 6). Forage chop length did not affect water intake (Table 6). The data on the sorting of the cows by screen of the PSPS is given in Table 7. The least squares means of the sorting of the fraction of the diets retained by the $19-\mathrm{mm}$ screen was lower than $100 \%$ for all diets. The least squares means of the sorting of the fractions retained by the $1.18-\mathrm{mm}$ screen and the $8-\mathrm{mm}$ screen were greater that $100 \%$ for all diets, with the exception of the sorting of the fraction retained by the $1.18-\mathrm{mm}$ 
Table 6. Dry matter intake, orts, and water intake of cows fed experimental diets containing shorter (6 $\mathrm{mm})$ or longer $(19 \mathrm{~mm})$ chop lengths of alfalfa and oat silages

\begin{tabular}{lccccccccc}
\hline & \multicolumn{4}{c}{ Diet $^{1}$} & & \multicolumn{3}{c}{ Effect $^{2}$} \\
\cline { 2 - 4 } \cline { 8 - 10 } Item & ALOL & ALOS & ASOL & ASOS & SE & & AC & OC & AC $\times$ OC \\
\hline DMI, kg/d & 19.0 & 21.3 & 19.8 & 21.1 & 0.48 & & 0.50 & $<0.001$ & 0.34 \\
Orts, \% of feed provided & 11.7 & 6.4 & 7.1 & 6.5 & 2.67 & & 0.38 & 0.26 & 0.37 \\
Water intake, L/d & 77.8 & 82.3 & 82.4 & 81.6 & 2.00 & 0.33 & 0.36 & 0.20 \\
\hline
\end{tabular}

${ }^{1} \mathrm{ALOL}=$ alfalfa longer chop and oat longer chop; ALOS = alfalfa longer chop and oat shorter chop; ASOL = alfalfa short chop and oat longer chop; ASOS = alfalfa short chop and oat shorter chop.

${ }^{2} \mathrm{AC}=$ alfalfa chop effect; $\mathrm{OC}=$ oat chop effect; $\mathrm{AC} \times \mathrm{OC}=$ interaction effect of alfalfa and oat chop lengths.

screen of the diets containing longer chop alfalfa silage and shorter chop oats silage. However, this sorting ranged only from 101.3 to $103.8 \%$. The sorting of the fraction retained by the bottom pan also differed significantly from $100 \%$ and ranged from 154.5 to $173.5 \%$ among diets. This shows that cows sorted against feed particles that were longer than $19 \mathrm{~mm}$ and sorted in favor of feed particles shorter than $8 \mathrm{~mm}$. This sorting against feed particles longer than $19 \mathrm{~mm}$ was greater for the diets containing the longer chop oat silage compared with the diets containing the shorter chop oat silage. The selection in favor of dietary particles with a length between 1.18 and $8 \mathrm{~mm}$ was greater $(P=0.03)$ for the diets containing the longer chop alfalfa silage compared with diets containing the shorter chop alfalfa silage.

Times spent eating, ruminating, chewing, and chewing per kilogram of DM were not affected by forage chop length and averaged $361,575,936 \mathrm{~min} / \mathrm{d}$, and $49.7 \mathrm{~min} /$ $\mathrm{kg}$ of DM, respectively, across diets (Table 8). The meal criterion did not differ among diets (Table 9). As a result, a pooled criterion of $21.3 \mathrm{~min}$ was used for the determination of the meal characteristics. The particle lengths of alfalfa silage and oat silage did not affect the number of meals per day, nor the average daily meal duration, meal size, and eating rate (Table 9). During the first meal after feed delivery, more feed was eaten, and the duration of eating was longer compared with other meals. Reducing the chop length of both forages reduced the duration and size of this first meal.

The proportions of daily DMI consumed within 3-h periods relative to feeding delivery are given in Table 10. Period after feeding affected the proportion of the daily DMI consumed during these periods. The proportion of the daily intake of TMR eaten within $3 \mathrm{~h}$ after feed delivery was greater than that eaten during any other 3-h interval. The interactions between alfalfa chop and period after feeding and oat chop and period after feeding were both significant $(P<0.0005$ and $P<$ 0.005 , respectively). Reducing the chop length of alfalfa silage and oat silage both reduced the proportion of the daily DMI of TMR eating during the first $3 \mathrm{~h}$ after feed delivery.

\section{Rumen Fermentation and Blood Variables}

The chop lengths of alfalfa silage oat silage did not affect the average daily rumen $\mathrm{pH}$, the durations of time during which rumen $\mathrm{pH}$ was below $\mathrm{pH} 6$ and below $\mathrm{pH} 5.6$, and the areas below $\mathrm{pH} 6$ and below $\mathrm{pH} 5.6$ (Table 11). Rumen liquid outflow rate was also not affected by the forage particle size in our study and varied from 11.3 to $12.1 \% / \mathrm{h}$ among diets. Reducing particle sizes of alfalfa silage and oat silage did not affect the

Table 7. Sorting (\%) of cows of Penn State Particle Separator fractions of the experimental diets containing shorter $(6 \mathrm{~mm})$ or longer $(19 \mathrm{~mm})$ chop lengths of alfalfa and oat silages

\begin{tabular}{|c|c|c|c|c|c|c|c|c|}
\hline \multirow[b]{2}{*}{ Sorting $^{1}$} & \multicolumn{4}{|c|}{ Diet $^{2}$} & \multirow[b]{2}{*}{ SE } & \multicolumn{3}{|c|}{ Effect $^{3}$} \\
\hline & ALOL & ALOS & ASOL & ASOS & & $\mathrm{AC}$ & $\mathrm{OC}$ & $\mathrm{AC} \times \mathrm{OC}$ \\
\hline Top screen (19 mm) & 89.3 & 85.2 & 89.0 & 81.3 & 2.70 & 0.45 & 0.05 & 0.50 \\
\hline Second screen (8 mm) & 102.8 & 102.0 & 101.8 & 102.0 & 0.34 & 0.16 & 0.47 & 0.17 \\
\hline Third screen $(1.18 \mathrm{~mm})$ & 103.0 & 103.8 & 101.3 & 102.0 & 0.73 & 0.03 & 0.32 & 0.95 \\
\hline Bottom pan & 162.5 & 173.5 & 168.3 & 154.5 & 12.4 & 0.60 & 0.91 & 0.34 \\
\hline
\end{tabular}

${ }^{1}$ Sorting by screen was calculated on as-fed basis as [100 $\times$ (actual intake/predicted intake)]; Leonardi et al. (2005).

${ }^{2} \mathrm{ALOL}=$ alfalfa longer chop and oat longer chop; ALOS = alfalfa longer chop and oat shorter chop; ASOL = alfalfa short chop and oat longer chop; ASOS = alfalfa short chop and oat shorter chop.

${ }^{3} \mathrm{AC}=$ alfalfa chop effect; $\mathrm{OC}=$ oat chop effect; $\mathrm{AC} \times \mathrm{OC}=$ interaction effect of alfalfa and oat chop lengths. 
Table 8. Time spent eating, ruminating, and chewing (eating and ruminating) of cows recorded by video monitoring (with scan sampling at 5-min intervals) fed experimental diets containing shorter $(6 \mathrm{~mm})$ or longer $(19 \mathrm{~mm})$ chop lengths of alfalfa and oat silages

\begin{tabular}{|c|c|c|c|c|c|c|c|c|}
\hline \multirow[b]{2}{*}{ Item } & \multicolumn{4}{|c|}{$\operatorname{Diet}^{1}$} & \multirow[b]{2}{*}{ SE } & \multicolumn{3}{|c|}{ Effect ${ }^{2}$} \\
\hline & ALOL & ALOS & ASOL & ASOS & & $\mathrm{AC}$ & $\mathrm{OC}$ & $\mathrm{AC} \times \mathrm{OC}$ \\
\hline Eating, h/d & 360 & 382 & 353 & 352 & 12.6 & 0.17 & 0.31 & 0.29 \\
\hline Ruminating, $\min / \mathrm{d}$ & 571 & 567 & 565 & 596 & 16.4 & 0.37 & 0.27 & 0.17 \\
\hline Total chewing & & & & & & & & \\
\hline $\operatorname{Min} / \mathrm{d}$ & 931 & 949 & 917 & 948 & 19.7 & 0.68 & 0.13 & 0.71 \\
\hline $\mathrm{Min} / \mathrm{kg}$ of $\mathrm{DM}$ & 50.9 & 48.8 & 49.7 & 49.1 & 5.16 & 0.59 & 0.16 & 0.43 \\
\hline
\end{tabular}

${ }^{1} \mathrm{ALOL}=$ alfalfa longer chop and oat longer chop; ALOS = alfalfa longer chop and oat shorter chop; ASOL = alfalfa short chop and oat longer chop; ASOS = alfalfa short chop and oat shorter chop.

${ }^{2} \mathrm{AC}=$ alfalfa chop effect; $\mathrm{OC}=$ oat chop effect; $\mathrm{AC} \times \mathrm{OC}=$ interaction effect of alfalfa and oat chop lengths.

concentrations of VFA, the acetate to propionate ratio, and ammonia in the rumen (Table 12). The plasma concentrations of glucose, urea, and lactate were also not affected by the chop lengths of oat silage and alfalfa silage (Table 13).

\section{Milk Production and Composition}

The chop length of alfalfa and oat silage did not affect milk yield, milk fat percentage, milk protein percentage, or milk protein yield (Table 14). Reducing the chop length of oat silage tended to increase $(P=0.09)$ milk fat yield, whereas the chop length of alfalfa silage did not affect milk fat yield. Daily milk yield, milk fat percentage, and milk protein percentage averaged $36.1 \mathrm{~kg} /$ $\mathrm{d}, 3.00 \%$, and $3.16 \%$, respectively, across all diets.

\section{DISCUSSION}

Dairyland Laboratories (2007) reported normal ranges of the $\mathrm{pH}$ of legume silages and small grain silages of between 4.2 and 5.5 and between 3.7 and 5.5, respectively. The $\mathrm{pH}$ of the longer chop alfalfa silage was higher than the range for legume silages, but the $\mathrm{pH}$ of the shorter chop alfalfa silage fell within this range. The $\mathrm{pH}$ values of both oat silages were within the normal range for small grain silages silage reported by Dairyland Laboratories (2007).

Kung and Shaver (2000) recommended target levels for $\mathrm{pH}$, ammonia-N content, and lactate content of legume silage of $\mathrm{pH} 4.0$ to 4.3 , lower than $12 \%$ of $\mathrm{CP}$, and 4.0 to $6.0 \%$ of DM, respectively. Kononoff and Heinrichs (2003a) reported a $\mathrm{pH}$, ammonia- $\mathrm{N}$ content, and lactate content of alfalfa silage of 4.7, $12.7 \%$ of $\mathrm{CP}$, and $5.9 \%$ of DM, respectively. Hence, the $\mathrm{pH}$ and ammonia-N content of the alfalfa silages in our study were greater and the lactate contents of alfalfa silages in our study were lower than recommended by Kung and Shaver (2000) and found by Kononoff and Heinrichs (2003a). Nevertheless, the $\mathrm{pH}$ and ammonia- $\mathrm{N}$ content of the alfalfa silage chopped at $6 \mathrm{~mm}$ were lower and the lactate content of this silage was greater than the 5.1, $4.7 \%$ of DM, and $17.3 \%$ of CP found by Bhandari et al. (2007) in alfalfa silage chopped at $10 \mathrm{~mm}$. Thus, reduc-

Table 9. Meal patterns of cows fed experimental diets containing a shorter (6 mm) or longer (19 $\mathrm{mm})$ chop lengths of alfalfa and oat silages

\begin{tabular}{|c|c|c|c|c|c|c|c|c|}
\hline \multirow[b]{2}{*}{ Item } & \multicolumn{4}{|c|}{$\operatorname{Diet}^{1}$} & \multirow[b]{2}{*}{$\mathrm{SE}$} & \multicolumn{3}{|c|}{ Effect $^{2}$} \\
\hline & ALOL & ALOS & ASOL & ASOS & & $\mathrm{AC}$ & $\mathrm{OC}$ & $\mathrm{AC} \times \mathrm{OC}$ \\
\hline Number of meals/d & 8.23 & 8.09 & 8.47 & 7.24 & 0.62 & 0.47 & 0.20 & 0.12 \\
\hline Meal criterion, min & 24.5 & 18.9 & 19.6 & 22.2 & 4.53 & 0.87 & 0.76 & 0.39 \\
\hline \multicolumn{9}{|l|}{ All meals } \\
\hline Meal duration, min & 35.4 & 36.8 & 35.8 & 35.4 & 3.84 & 0.19 & 0.27 & 0.80 \\
\hline Meal size, kg of DM & 2.42 & 2.65 & 2.30 & 2.65 & 0.25 & 0.47 & 0.26 & 0.21 \\
\hline Eating rate, $\mathrm{g}$ of $\mathrm{DM} / \mathrm{min}$ & 55.9 & 57.3 & 60.3 & 68.3 & 8.02 & 0.90 & 0.33 & 0.51 \\
\hline \multicolumn{9}{|l|}{ First meal } \\
\hline Meal duration, min & 138.6 & 136.7 & 127.4 & 103.5 & 7.20 & $<0.05$ & 0.03 & 0.09 \\
\hline Meal size, kg of DM & 8.77 & 8.30 & 8.00 & 7.20 & 0.57 & 0.02 & 0.04 & 0.66 \\
\hline Eating rate, $\mathrm{g}$ of $\mathrm{DM} / \mathrm{min}$ & 63.3 & 60.7 & 62.8 & 69.6 & 5.15 & 0.27 & 0.49 & 0.46 \\
\hline
\end{tabular}

${ }^{1} \mathrm{ALOL}=$ alfalfa longer chop and oat longer chop; ALOS = alfalfa longer chop and oat shorter chop; ASOL = alfalfa short chop and oat longer chop; ASOS = alfalfa short chop and oat short chop.

${ }^{2} \mathrm{AC}=$ alfalfa chop effect; $\mathrm{OC}=$ oat chop effect; $\mathrm{AC} \times \mathrm{OC}=$ interaction effect of alfalfa and oat chop lengths. 
Table 10. Proportion of DMI consumed within 3-h periods relative to feed delivery of high-yielding dairy cows fed with diets containing a shorter $(6 \mathrm{~mm})$ or longer $(19 \mathrm{~mm})$ chop lengths of alfalfa and oat silages

\begin{tabular}{lrrrrrrrr}
\hline \multirow{2}{*}{$\begin{array}{l}\text { Time relative } \\
\text { to feed } \\
\text { delivery, h }\end{array}$} & \multicolumn{4}{c}{ Diet $^{1}$} & & \multicolumn{3}{c}{ Effect $^{2}$} \\
\cline { 2 - 5 } \cline { 6 - 8 } & ALOL & ALOS & ASOL & ASOS & SE & AC & OC & AC $\times$ OC \\
\hline 0 to 3 & 42.1 & 36.3 & 36.1 & 30.8 & 2.29 & $<0.05$ & $<0.05$ & 0.91 \\
3 to 6 & 18.2 & 21.5 & 19.3 & 17.4 & 1.68 & 0.37 & 0.69 & 0.12 \\
6 to 9 & 12.6 & 10.0 & 12.3 & 10.5 & 1.44 & 0.95 & 0.06 & 0.74 \\
9 to 12 & 9.3 & 10.9 & 13.2 & 17.9 & 1.66 & $<0.01$ & 0.07 & 0.35 \\
12 to 15 & 11.9 & 11.7 & 9.2 & 10.4 & 1.61 & 0.23 & 0.76 & 0.67 \\
15 to 18 & 2.1 & 3.5 & 2.0 & 2.3 & 0.81 & 0.40 & 0.31 & 0.46 \\
18 to 21 & 2.4 & 2.7 & 2.2 & 3.7 & 0.78 & 0.57 & 0.24 & 0.45 \\
21 to 24 & 1.4 & 3.3 & 5.6 & 7.1 & 0.99 & $<0.01$ & 0.10 & 0.82 \\
\hline
\end{tabular}

${ }^{1} \mathrm{ALOL}=$ alfalfa longer chop and oat longer chop; ALOS = alfalfa longer chop and oat shorter chop; ASOL = alfalfa short chop and oat longer chop; ASOS = alfalfa short chop and oat short chop.

${ }^{2} \mathrm{AC}=$ alfalfa chop effect; $\mathrm{OC}=$ oat chop effect; $\mathrm{AC} \times \mathrm{OC}=$ interaction effect of alfalfa and oat chop lengths.

ing the chop length of alfalfa silage and oat silage improved the fermentation profile.

Kung and Shaver (2000) did not give recommendations for the fermentation profile of oat silage, but recommended target levels for the $\mathrm{pH}$, ammonia-N content, and lactate content of corn silage of 4.0 to 4.5 , $<8 \%$ of $\mathrm{CP}$, and 5.0 to $10.0 \%$ of DM, respectively. The average $\mathrm{pH}$, ammonia- $\mathrm{N}$ content, and lactate content of barley silage reported by Yang and Beauchemin (2006a) were $3.92,4.1 \%$ of $\mathrm{CP}$, and $6.7 \%$ of DM, respectively. Thus, the $\mathrm{pH}$ and ammonia-N content of the alfalfa silages in our study were greater and the lactate contents of oat silages in our study were lower than recommended by Kung and Shaver (2000). These values were also lower than those observed by Yang and Beauchemin (2006a) for barley silage. However, the $\mathrm{pH}$ of the oat silage chopped at $6 \mathrm{~mm}$ was lower than the 5.0 reported by Bhandari et al. (2007) for corn silage chopped at $10 \mathrm{~mm}$ and very close to the upper limit of the corn silage $\mathrm{pH}$ recommended by Kung and Shaver (2000).

The proportions retained by the $19-\mathrm{mm}$ screen were much greater than the 10 to $20 \%$ and the 3 to $8 \%$ recommended for haylage and corn silage, respectively, by Heinrichs and Kononoff (2002). The proportions of the silages retained by the $8-\mathrm{mm}$ screen agree with the recommendations from Heinrichs and Kononoff (2002). The NDF content of all diets was greater than the minimum of $34 \%$ of DM recommended by Beauchemin (1991) for barley-based diets. The proportion of the diet retained by the 19-mm PSPS screen of all diets, with the exception of the diet containing the shorter chop of both silages, was greater than recommended by Heinrichs and Kononoff (2002). The proportion of the diet retained by the 8-mm PSPS screen was greater than the proportion recommended by Heinrichs and Kononoff (2002) for all diets. Reducing the chop lengths of alfalfa silage and oats silage decreased the geometrical aver-

Table 11. Rumen parameters based on continuous rumen $\mathrm{pH}$ monitoring using indwelling probes in cows fed diets containing shorter $(6 \mathrm{~mm})$ or longer $(19 \mathrm{~mm})$ chop lengths of alfalfa and oat silages

\begin{tabular}{|c|c|c|c|c|c|c|c|c|}
\hline \multirow[b]{2}{*}{ Item } & \multicolumn{4}{|c|}{$\operatorname{Diet}^{1}$} & \multirow[b]{2}{*}{ SE } & \multicolumn{3}{|c|}{ Effect $^{2}$} \\
\hline & ALOL & ALOS & ASOL & ASOS & & $\mathrm{AC}$ & $\mathrm{OC}$ & $\mathrm{AC} \times \mathrm{OC}$ \\
\hline Average daily $\mathrm{pH}$ & 6.21 & 6.22 & 6.27 & 6.27 & 0.07 & 0.30 & 0.94 & 0.94 \\
\hline $\mathrm{T}<6, \mathrm{~min} / \mathrm{d}^{3}$ & 490.3 & 482.1 & 394.1 & 434.8 & 94.9 & 0.33 & 0.82 & 0.73 \\
\hline $\mathrm{T}<5.6, \mathrm{~min} / \mathrm{d}^{4}$ & 197.2 & 128.1 & 120.6 & 129.4 & 59.6 & 0.41 & 0.50 & 0.39 \\
\hline $\mathrm{A}<6, \min \times \mathrm{pH} / \mathrm{d}^{5}$ & 172.6 & 123.9 & 122.0 & 129.4 & 45.6 & 0.51 & 0.55 & 0.42 \\
\hline $\mathrm{A}<5.6, \min \times \mathrm{pH} / \mathrm{d}^{6}$ & 37.0 & 14.8 & 21.7 & 19.5 & 12.2 & 0.56 & 0.21 & 0.29 \\
\hline Rumen liquid outflow rate, $\% / \mathrm{h}$ & 11.3 & 11.8 & 12.1 & 11.5 & 0.8 & 0.66 & 0.89 & 0.35 \\
\hline
\end{tabular}

${ }^{1} \mathrm{ALOL}=$ alfalfa longer chop and oat longer chop; ALOS = alfalfa longer chop and oat shorter chop; ASOL = alfalfa short chop and oat longer chop; ASOS = alfalfa short chop and oat short chop.

${ }^{2} \mathrm{AC}=$ alfalfa chop effect; $\mathrm{OC}=$ oat chop effect; $\mathrm{AC} \times \mathrm{OC}=$ interaction effect of alfalfa and oat chop lengths.

${ }^{3} \mathrm{~T}<6=$ time below rumen $\mathrm{pH} 6.0$ per day.

${ }^{4} \mathrm{~T}<5.6=$ time below rumen $\mathrm{pH} 5.6$ per day.

${ }^{5} \mathrm{~A}<6=$ area below rumen $\mathrm{pH} 6.0$ per day.

${ }^{6} \mathrm{~A}<5.6=$ area below rumen $\mathrm{pH} 6.0$ per day. 
Table 12. Rumen fluid composition based on spot sampling using a stomach tube for diets containing a shorter $(6 \mathrm{~mm})$ or longer $(19 \mathrm{~mm})$ chop lengths of alfalfa and oat silages

\begin{tabular}{|c|c|c|c|c|c|c|c|c|}
\hline \multirow[b]{2}{*}{ Item } & \multicolumn{4}{|c|}{$\operatorname{Diet}^{1}$} & \multirow[b]{2}{*}{$\mathrm{SE}$} & \multicolumn{3}{|c|}{ Effect $^{2}$} \\
\hline & ALOL & ALOS & ASOL & ASOS & & $\mathrm{AC}$ & $\mathrm{OC}$ & $\mathrm{AC} \times \mathrm{OC}$ \\
\hline \multicolumn{9}{|l|}{ VFA, $\mathrm{m} M$} \\
\hline Total & 121.0 & 125.8 & 116.2 & 126.9 & 5.56 & 0.91 & 0.34 & 0.64 \\
\hline Acetate (A) & 77.6 & 82.9 & 74.1 & 83.5 & 4.85 & 0.89 & 0.37 & 0.70 \\
\hline Propionate $(\mathrm{P})$ & 25.6 & 23.3 & 24.1 & 24.4 & 1.28 & 0.92 & 0.54 & 0.33 \\
\hline Butyrate & 13.7 & 14.8 & 13.9 & 14.6 & 0.74 & 0.93 & 0.21 & 0.66 \\
\hline Other & 3.9 & 4.8 & 4.0 & 4.4 & 0.27 & 0.93 & 0.03 & 0.21 \\
\hline $\mathrm{A}: \mathrm{P}$ & 3.4 & 3.7 & 3.4 & 3.5 & 0.27 & 0.76 & 0.75 & 0.77 \\
\hline Ammonia, mg/dL & 10.9 & 11.6 & 12.1 & 11.1 & 0.65 & 0.73 & 0.56 & 0.21 \\
\hline
\end{tabular}

${ }^{1} \mathrm{ALOL}$ = alfalfa longer chop and oat longer chop; ALOS = alfalfa longer chop and oat shorter chop; ASOL = alfalfa shorter chop and oat longer chop; ASOS = alfalfa shorter chop and oat short chop.

${ }^{2} \mathrm{AC}=$ alfalfa chop effect; $\mathrm{OC}=$ oat chop effect; $\mathrm{AC} \times \mathrm{OC}=$ interaction effect of alfalfa and oat chop lengths.

age feed particle length of the diets, but did not affect peNDF $_{\mathrm{PS}}, \mathrm{peNDF}_{>1.18}$, and peNDF $\mathrm{NDF}_{\mathrm{N}}$. One reason for the absence of an effect on physically effective fiber was that a reduction of the chop length of the alfalfa silage decreased the proportion of the diet retained by the 19$\mathrm{mm}$ screen, but increased the proportion of the diet retained by the $8-\mathrm{mm}$ screen. As the fractions retained by both of these screens were considered physically effective, such a shift between these screens did not affect values for physically effective fiber. It has been suggested that $1.18 \mathrm{~mm}$ is a threshold for the retention of feed particles in the rumen in the reticulum and the rumen (Poppi et al., 1985; Mertens, 1997). This particle length might, therefore, affect chewing behavior. This is also a reason why a $1.18-\mathrm{mm}$ screen was included in the PSPS (Kononoff and Heinrichs, 2002). Hence, the absence of an effect of forage chop length on chewing behavior might be related to the absence of a forage chop length effect on peNDF $>1.18$. As the total chewing time and rumen $\mathrm{pH}$, as well as the various measures of physically effective fiber, did not differ among diets, it was not possible to determine which measure of physically effective fiber is the best predictor of rumen buffering and rumen $\mathrm{pH}$. The absence of a diet effect on chewing time and rumen $\mathrm{pH}$ also prevented assessing if the average fed particle length is a better indicator of rumen buffering that the measures of physically effective fiber used in this study.

The absence of an effect of the chop length of alfalfa silage on DMI is in agreement with Bhandari et al. (2007), who also found that reducing the chop length of alfalfa silage from 19 to $10 \mathrm{~mm}$ did not affect DMI. However, in their study a similar reduction in the chop length of corn silage increased DMI. In that study, the lower DMI with the 19-mm corn silage chop length was attributed to a failure to fully fractionate corn cobs at this chop length, which resulted in unpalatable chunks. This does not explain the increased DMI resulting from the reduction in the oat silage chop length in our study, because the longer chop length did not result in unpalatable chunks. Krause et al. (2002a) reduced the average geometric particle length of alfalfa silage from 13.6 to $3.7 \mathrm{~mm}$ and incorporated these silages into a diet containing $39.3 \%$ of DM of this silage. They also found that this reduction did not affect DMI. However, Kononoff and Heinrichs (2003a) found that reducing the average geometric particle length of alfalfa haylage from 18.1 to $8.9 \mathrm{~mm}$ and including $50 \%$ of DM of alfalfa haylage in a TMR increased DMI. Reasons for this discrepancy between the study from Kononoff and Heinrichs (2003a) and other studies may be attributed to the longer alfalfa particle length and the greater dietary

Table 13. Concentrations of metabolites in blood plasma for experimental diets containing shorter (6 mm) or longer $(19 \mathrm{~mm})$ chop lengths of alfalfa and oat silages

\begin{tabular}{|c|c|c|c|c|c|c|c|c|}
\hline \multirow[b]{2}{*}{ Item } & \multicolumn{4}{|c|}{$\operatorname{Diet}^{1}$} & \multirow[b]{2}{*}{$\mathrm{SE}$} & \multicolumn{3}{|c|}{ Effect $^{2}$} \\
\hline & ALOL & ALOS & ASOL & ASOS & & $\mathrm{AC}$ & $\mathrm{OC}$ & $\mathrm{AC} \times \mathrm{OC}$ \\
\hline Glucose, $\mathrm{m} M$ & 3.78 & 3.61 & 3.75 & 3.78 & 0.06 & 0.13 & 0.11 & 0.03 \\
\hline Lactate, $\mathrm{m} M$ & 1.05 & 0.89 & 0.89 & 0.87 & 0.08 & 0.11 & 0.11 & 0.25 \\
\hline Urea, $\mathrm{m} M$ & 6.0 & 6.0 & 5.9 & 5.8 & 0.16 & 0.15 & 0.76 & 0.78 \\
\hline
\end{tabular}

${ }^{1} \mathrm{ALOL}=$ alfalfa longer chop and oat longer chop; ALOS = alfalfa longer chop and oat shorter chop; ASOL = alfalfa short chop and oat longer chop; ASOS = alfalfa short chop and oat shorter chop.

${ }^{2} \mathrm{AC}=$ alfalfa chop effect; $\mathrm{OC}=$ oat chop effect; $\mathrm{AC} \times \mathrm{OC}=$ interaction effect of alfalfa and oat chop lengths. 
Table 14. Milk production of cows fed experimental diets containing a shorter (6 mm) or longer (19 $\mathrm{mm})$ chop lengths of alfalfa and oat silages

\begin{tabular}{|c|c|c|c|c|c|c|c|c|}
\hline \multirow[b]{2}{*}{ Item } & \multicolumn{4}{|c|}{$\operatorname{Diet}^{1}$} & \multirow[b]{2}{*}{$\mathrm{SE}$} & \multicolumn{3}{|c|}{ Effect ${ }^{2}$} \\
\hline & ALOL & ALOS & ASOL & ASOS & & $\mathrm{AC}$ & $\mathrm{OC}$ & $\mathrm{AC} \times \mathrm{OC}$ \\
\hline Milk yield, kg/d & 35.1 & 36.7 & 36.3 & 36.2 & 1.10 & 0.59 & 0.36 & 0.28 \\
\hline \multicolumn{9}{|l|}{ Milk component } \\
\hline Fat, $\%$ & 2.95 & 3.06 & 2.99 & 3.03 & 0.14 & 0.91 & 0.42 & 0.78 \\
\hline Fat yield, kg/d & 1.03 & 1.12 & 1.08 & 1.11 & 0.04 & 0.53 & 0.09 & 0.31 \\
\hline Protein, \% & 3.18 & 3.14 & 3.16 & 3.18 & 0.04 & 0.71 & 0.74 & 0.28 \\
\hline Protein yield, kg/d & 1.09 & 1.15 & 1.13 & 1.16 & 0.04 & 0.37 & 0.12 & 0.58 \\
\hline
\end{tabular}

${ }^{1} \mathrm{ALOL}=$ alfalfa longer chop and oat longer chop; ALOS = alfalfa longer chop and oat shorter chop; ASOL = alfalfa short chop and oat longer chop; ASOS = alfalfa short chop and oat short chop.

${ }^{2} \mathrm{AC}=$ alfalfa chop effect; $\mathrm{OC}=$ oat chop effect; $\mathrm{AC} \times \mathrm{OC}=$ interaction effect of alfalfa and oat chop lengths.

inclusion rate of alfalfa in their study. Also, in contrast to our results, Krause and Combs (2003) observed a reduction in DMI when the particle length of alfalfa silage was decreased. This might be explained by the very low rumen $\mathrm{pH}$ resulting from feeding the diets with a short particle length of alfalfa, which can result in SARA and decreased feed intake (Stone, 2004).

With the exception of a study by Leonardi et al. (2005), information on the effects of particle length of oat silage in cattle is lacking. As oats and barley are both cereal grains, barley silage is more representative of oat silage than corn silage. In agreement with our study, Leonardi et al. (2005) found that a reduction in average particle length of TMR from 6.68 to $4.35 \mathrm{~mm}$, achieved by reducing the average particle length of oat silage, increased DMI of dairy cows fed diets containing $49.8 \%$ of DM as concentrate and $25.1 \%$ of DM as oat silage. Yang and Beauchemin (2006b) reduced the chop length of barley silage from 9.5 to $4.8 \mathrm{~mm}$ and incorporated these silages in a TMR containing $46.6 \%$ of DM as barley silage and barley grain-based concentrate. In contrast to our study, these authors found that this reduction in the chop length of barley silage did not affect the DMI of dairy cows. Conversely, Kononoff et al. (2000) found that reducing the chop length of barley silage from 9.0 to $4.8 \mathrm{~mm}$ reduced the DMI of dairy cows fed TMR diets 55\% with DM as barley grain concentrate. The discrepancies between the studies conducted by Kononoff et al. (2000) and Yang and Beauchemin (2006ab) might be explained by differences in chop length of the silage. As indicated above, Kononoff et al. (2000) and Yang and Beauchemin (2006ab) used a shorter chop length with a narrower range of particle size length than that of the current study. In our study the DMI ranged from 3.11 to $3.49 \%$ of BW/d. This range is similar to those reported by Kononoff and Heinrichs (2003a) and Yang and Beauchemin (2006a,b).

The absence of an effect of forage chop length on chewing behavior disagrees with several earlier stud- ies. Krause et al. (2002b) found that reducing the particle length of the alfalfa silage from 13.6 to $3.7 \mathrm{~mm}$ reduced the time spent eating and time spent ruminating from 300 to $232 \mathrm{~min} / \mathrm{d}$ and from 468 to $351 \mathrm{~min} / \mathrm{d}$, respectively. These authors also found that time spent chewing was reduced from 30.9 to $24.9 \mathrm{~min} / \mathrm{d}$, when the alfalfa silage was incorporated in diets containing $36.3 \%$ of DM as either high-moisture shelled corn or dried cracked shelled corn and $39.3 \%$ of DM alfalfa silage. Kononoff and Heinrichs (2003a) fed TMR containing $50 \%$ of DM of alfalfa haylage and $50 \%$ of DM as concentrate to lactating dairy cows and found that reducing the average length of the alfalfa haylage from 18.1 to $8.9 \mathrm{~mm}$ reduced time spent eating from 298 to $262 \mathrm{~min} / \mathrm{d}$. In their study, reducing the alfalfa haylage particle length did not affect time spent ruminating, which averaged $480 \mathrm{~min} / \mathrm{d}$ across diets, but time spent chewing (eating and ruminating) per kilogram of DMI was reduced from 37.9 to $31.2 / \mathrm{kg}$ of DM. Yang and Beauchemin (2006a) fed TMR containing $46.1 \%$ of DM as barley silage and $53.9 \%$ of DM as concentrate and observed that reducing the chop length of barley silage from 9.5 to $4.8 \mathrm{~mm}$ did not affect time spent eating, but reduced time spent ruminating and total time spent chewing from 440 to $363 \mathrm{~min} / \mathrm{d}$ and from 719 to 622 $\mathrm{min} / \mathrm{d}$, respectively, and reduced time spent chewing per kilogram of DMI from 38.3 to $32.5 \mathrm{~min} / \mathrm{kg}$ of DM. The discrepancies between our study and the earlier studies might be explained by the longer times spent eating, ruminating, and chewing in our study. When the physically effective fiber content of a diet fully stimulates chewing, further increases in physically effective fiber do not further increase chewing activity (Mertens, 1997). Hence, a physiological limit might exist, above which an increase in dietary particle length no longer increases chewing. As such, all of the diets in our study might have been above that limit.

The high DMI in the $3 \mathrm{~h}$ after feed delivery compared with that during any other 3 -h period agrees with sev- 
eral studies that showed that provision of fresh feed stimulated eating of dairy cows in tie-stalls and freestalls (Tolkamp et al., 2000; Beauchemin et al., 2002; De Vries et al., 2003). During the first $3 \mathrm{~h}$ after feed delivery the DMI of diets containing the longer chop of alfalfa silage and oat silage were greater than that of diets containing the shorter chop of these silages. This agrees with the observation that the duration and size of the first meal after feed delivery was also reduced when forage chop length decreased.

Despite an effect of forage chop length on the first meal after feed delivery, it did not affect the number of meals per day, or the daily averages of meal duration, meal size, and eating rate. This difference in impact of forage chop length on the size and duration of the first meal after feed delivery, but not on the average size and duration of meals, might be explained by the comparative large size of this first meal, because the difference in size might result in differences in the mechanism regulating meal size. However, as daily DMI did not differ among diets, cows compensated for a smaller meal after feed delivery by increasing feed intake later in the day.

The absence of an effect of forage chop length on the daily averages of meal size and meal duration agrees with the absence of an effect of forage chop length on time spent eating. Other studies examining the effect of forage particle length did not measure meal patterns. This complicates comparisons among these studies. Using a 20-min meal criterion, which is similar to the 21.3-min meal criterion used in our study, Beauchemin et al. (2002) reported that lactating dairy cows in a tiestall on TMR had 10 to 11 meals per day, with average meal size ranging from 1.86 to $1.91 \mathrm{~kg}$ of DM, average meal duration ranging from 36 to $39 \mathrm{~min}$, and average eating rate ranging from 48 to $57 \mathrm{~g}$ of $\mathrm{DM} / \mathrm{min}$ among diets. Dado and Allen (1994) also reported that dairy cows had on average 11 meals per day and an eating rate of $75 \mathrm{~g}$ of $\mathrm{DM} / \mathrm{min}$. Hence, the numbers of meals per day reported in the current study were lower than that reported by Dado and Allen (1994) and Beauchemin et al. (2002). The meal sizes were greater, and the meal durations were similar in our study compared with that of Beauchemin et al. (2002), and the eating rates (60.7 to $69.6 \mathrm{~g}$ of $\mathrm{DM} / \mathrm{min}$ ) were in between the values reported by Dado and Allen (1994) and Beauchemin et al. (2002). Using an individual meal criterion of $44.7 \pm 2.1 \mathrm{~min}$ for cows in a free-stall offered a TMR containing 58\% DM, Tolkamp et al. (2000) observed averages for meal duration and daily number of meals of $36.9 \mathrm{~min}$ and 6.1, respectively. As housing, meal criterion, and diets varied between our study and that of Tolkamp et al. (2000), it cannot be concluded that one of these factors was responsible for observed differences in the daily number of meals between these 2 studies.

The threshold rumen $\mathrm{pH}$ below which SARA occurs is under debate. Gozho et al. (2005) suggested that a rumen $\mathrm{pH}$ lower than 5.6 for $180 \mathrm{~min} / \mathrm{d}$ is indicative of SARA, but rumen $\mathrm{pH}$ thresholds of 5.5, 5.8, and 6.0 have also been used in the diagnosis of SARA (Krause et al., 2002b; Beauchemin et al., 2003; Yang and Beauchemin, 2006a). The duration of the rumen $\mathrm{pH}$ below 5.6 was greater than $120 \mathrm{~min} / \mathrm{d}$ for the all diets. Hence, it cannot be excluded that these diets did not induce SARA. Also, the milk fat percentages of all diets were low and an inversion of the milk fat percentage and milk protein percentage occurred for all diets, which suggest SARA (Kleen et al., 2003; Stone, 2004). The nutrient composition of the diets, however, did not suggest that cows were at risk for SARA, because dietary NDF content was greater than $34 \%$ of DM, which has been identified as the minimum required dietary NDF content to prevent SARA in barley-based diets (Beauchemin, 1991). Furthermore, the diets were coarser than recommended by Heinrichs and Kononoff (2002). Cows spent more time chewing than in the studies by Kononoff and Heinrichs (2003a), Krause et al. (2002b), and Yang and Beauchemin (2006a), in which SARA was not induced, which would suggest that in our study rumen buffering was sufficient for all diets. A possible explanation for the SARA in our study is that cows selected in favor of shorter feed particles and against longer feed particles. Similar sorting behavior was reported by Leonardi et al. (2005) and Bhandari et al. (2007) and shows that the diet consumed can vary substantially from the diet that is offered. The sorting in favor of the feed particles retained by the bottom pan of the PSPS was large, and ranged from 154.5 to $173.5 \%$ among diets. The implication of this sorting in favor of the finest feed particles might have been limited, because the fraction of the feed retained by the bottom pan only ranged from 2.2 to $3.0 \%$ among diets. On a 24-h basis, the sorting did not affect the intake of feed particles greatly, because only between 5 and $10 \%$ of orts were allowed. However, ingestion of small feed particles following feed delivery and a delay in the ingestion of longer feed particles after feed delivery would increase diurnal variation in rumen $\mathrm{pH}$ and, thereby, increase the risk of SARA. The daily average rumen $\mathrm{pH}$ ranged from 6.21 to 6.27 among diets, whereas the duration of the rumen $\mathrm{pH}$ below 5.6 ranged from 120.6 to $197.2 \mathrm{~min} / \mathrm{d}$ among diets, thereby showing that diurnal variation of rumen $\mathrm{pH}$ was substantial.

In our study, reducing the chop lengths of alfalfa silage and oat silage did not affect the $\mathrm{pH}$ and VFA in the rumen. Earlier studies also found that the particle length of alfalfa silage, corn silage, and oat silage did 
not affect rumen $\mathrm{pH}$ and total VFA (Krause and Combs, 2003; Leonardi et al., 2005). However, in contrast Yang and Beauchemin (2006a) found that reducing the chop length of barley silage affected total rumen VFA quadratically, without affecting rumen $\mathrm{pH}$. Results presented here are contrary to those reported by Krause et al. (2002b), who observed that reducing the average particle length of alfalfa silage reduced rumen $\mathrm{pH}$ and increased total rumen VFA and to those reported by Kononoff and Heinrichs (2003a), who found that reducing the particle length of alfalfa haylage increased total rumen VFA and quadratically affected rumen $\mathrm{pH}$. A possible explanation for the discrepancy between the data presented here and the studies conducted by Krause et al. (2002b), Kononoff and Heinrichs (2003a), and Yang and Beauchemin (2006a) could be that the dietary particle lengths were shorter in the earlier studies compared with our studies, and that a reduction in particle length has a greater impact on rumen $\mathrm{pH}$ in diets with short particle lengths compared with diets with long particle lengths (Mertens, 1997).

The shorter and longer chop length of both silages not only differed in particle size, but also in silage $\mathrm{pH}$ and VFA content. Next to feed particle size, silage $\mathrm{pH}$ can affect rumen $\mathrm{pH}$ (Thomas and Wilkinson, 1975). This effect cannot be quantified using results obtained in earlier studies on the effect of forage particle size in dairy cows, because most of these studies either did not chop silages at different lengths or did not determine silage $\mathrm{pH}$. Yang and Beauchemin (2006a) did chop barley silage at different lengths and determined silage $\mathrm{pH}$, as well as rumen $\mathrm{pH}$. However, because silage $\mathrm{pH}$ was not affected by forage chop length in this study, the effect of this $\mathrm{pH}$ on rumen conditions could also not be assessed.

A reduction in feed particle size increases the surface area of the particles for microbial attachment, which can increase the ruminal digestion and VFA production. However, a reduction in particle size may not result in increased ruminal digestion and VFA production because of increased particulate passage rate (Soita et al., 2002; Yang and Beauchemin, 2006a). Despite this, several studies with dairy cows have reported that a reduction in forage particle size does affect rumen digestion (Krause et al., 2002a; Yang and Beauchemin, 2006b).

The absence of an effect of forage chop length on the concentrations of acetate, propionate, and butyrate, as well as the acetate to propionate ratio agrees with Leonardi et al. (2005) and Yang and Beauchemin (2006a), who also observed that the particle length of oat silage and barely silage did not affect these VFA concentrations and this ratio. However, Krause et al. (2002a) and Kononoff and Heinrichs (2003a) found that reducing the particle length of alfalfa silage and alfalfa haylage reduced the acetate to propionate ratio. Comparison of the above studies suggests that studies in which reduction in forage particle size resulted in the greatest depression in rumen $\mathrm{pH}$, also showed the greatest reduction in acetate to propionate ratio. However, comparison of VFA concentrations among studies must be done with caution, because differences in the acidification and processing of rumen fluid after collection and before analysis can affect the loss of VFA and, therefore, affect VFA concentrations, and $\mathrm{pH}$ and VFA concentrations vary considerably among different location in the rumen (Duffield et al., 2004).

The lack of an effect of forage chop length on rumen ammonia is in agreement with Kononoff and Heinrichs (2003a) and Leonardi et al. (2005), who found that the particle length of alfalfa hay, alfalfa haylage, and oat silage did not affect rumen ammonia, suggesting that a reduction of forage particle length does not affect the protein digestion and uptake of ammonia by microbes in the rumen (Clark et al., 1992). In contrast, Yang and Beauchemin (2006a) found that rumen ammonia quadratically increased when the particle length of barley silage was decreased. In their study rumen digestion of dietary protein was not affected by forage particle size, but the microbial nitrogen as a percentage of nitrogen intake tended to increase when barley particle size was reduced. This demonstrates that factors other than rumen digestion of protein can affect the ruminal ammonia concentration, which might explain the discrepancies in forage particle length effect on rumen ammonia among studies.

Similar to our study, Kononoff and Heinrichs (2003a) also did not find that reducing the particle length of alfalfa affected the rumen liquid outflow rate, which averaged $16.4 \% / \mathrm{h}$ across diets. Our findings also agree with Yang and Beauchemin (2006b) who found that reducing the particle length of barely silage did not affect liquid outflow rate from the reticulorumen, which averaged $9.5 \% / \mathrm{h}$ across diets. In contrast to our study, Krause et al. (2002a) observed that reducing the particle length of alfalfa reduced the rumen liquid outflow rate from 13.8 to $11.8 \% / \mathrm{h}$. This reduction was contributed to a reduction in saliva production. The particle lengths of the diets from Krause et al. (2002a) were shorter than those in our study. As such, the physical effective fiber content of all the diets in our study could have been sufficient to fully stimulate chewing and saliva production (Mertens, 1997), which explained why diets did not differ in saliva production and rumen liquid outflow rate. Furthermore, although a reduction in forage particle size reduces chewing (Krause et al., 2002b; Beauchemin et al., 2003; Yang and Beauchemin, $2006 \mathrm{~b}$ ), this might not reduce saliva production (Mae- 
kawa et al., 2002; Beauchemin et al., 2003) and liquid rumen outflow rate, due to increased saliva production during resting; that is, in the absence of chewing (Maekawa et al., 2002).

The concentrations of glucose, urea, and lactate in blood plasma were similar to those reported by Plaizier (2004), but were lower than those reported by Bhandari et al. (2007), who reported concentrations of glucose, lactate, and urea that ranged between 4.12 and 4.20 $\mathrm{m} M, 1.02$ and $1.33 \mathrm{~m} M$, and 6.07 and $6.96 \mathrm{~m} M$, respectively. These differences between our study and that of Bhandari et al. (2007) might be explained by the greater dietary content of concentrate and CP in the earlier study. The plasma concentrations of glucose and urea were within the normal ranges from 2.4 to $4.2 \mathrm{mM}$ and from 2.8 to $8.8 \mathrm{~m} M$, respectively (Merck, 2006). These results agree with Bhandari et al. (2007), who found that reducing the chop length of alfalfa and corn silage from 19 to $10 \mathrm{~mm}$ also did not affect the blood plasma concentrations of glucose, urea, and lactate. Plaizier (2004) found that reducing the dietary particle length by replacing alfalfa silage with chopped hay increased blood glucose and decreased blood urea, but this was due to differences among these forages other than particle length.

Similar to our study, Krause et al. (2002a), Kononoff and Heinrichs (2003a), and Yang and Beauchemin (2006b) did not find that the particle lengths of alfalfa silage and barley silage affected milk yield. However, in contrast Leonardi et al. (2005) found that reducing the particle length of oat silage increased milk yield. Our results also agree with Krause et al. (2002a), Kononoff and Heinrichs (2003a), Leonardi et al. (2005), and Yang and Beauchemin (2006b), who also found that the particle lengths of alfalfa silage, barley silage, and oat silage did not affect milk fat percentage. Because rumen $\mathrm{pH}$ can affect milk fat percentage (Mertens, 1997; Griinari et al., 1998), the absence of a forage chop length effect on rumen $\mathrm{pH}$ will have contributed to the absence of this chop length effect on milk fat percentage. Mertens (1997) showed that milk fat percentage is more sensitive to differences in forage particle size when the percentage is low compared with when it is high. The fact that, despite the low milk fat percentages, forage chop length did not affect milk fat percentage might have been due the limited range of forage particle length, as well as due to the very limited differences in rumen $\mathrm{pH}$ and chemical composition among diets. Despite of an absence of an effect on milk fat percentage, our study showed that reducing the particle length of oat silage tended to increase milk fat yield. The increase in milk fat yield could be the result of an increase in DMI that occurred when the chop length of oat silage was reduced. A reduction in forage particle size can reduce milk fat, if it reduces rumen $\mathrm{pH}$, possibly through the increase in trans fatty acids in the rumen, or decreases the supply of acetate and butyrate (Mertens, 1997; Griinari et al., 1998). Because none of these were affected by reducing the chop lengths of alfalfa silage and oat silage, the absence of an effect on milk fat percentage was not unexpected.

The absence of a forage particle length effect on milk protein percentage agrees with Krause et al. (2002a), Leonardi et al. (2005), and Bhandari et al. (2007). However, in contrast to our study, Kononoff and Heinrichs (2003a) found a quadratic effect of the particle length of alfalfa silage on milk protein percentage, but not on milk protein yield. Also, Leonardi et al. (2005) found that reduced particle length of oat silage increased milk true protein yield, whereas Yang and Beauchemin (2006b) found that reducing the particle length of barley silage increased milk protein percentage without affecting milk protein yield. The discrepancy between the studies from Kononoff and Heinrichs (2003a) and our study might be related to the relatively low milk protein percentages in the earlier study, which ranged from 2.82 to $2.93 \%$ among diets. Although Leonardi et al. (2005) reported true protein and nontotal protein, their values for true protein in milk also suggest that their concentrations of milk protein were much lower than those in our study. The lower milk protein percentages in the studies from Kononoff and Heinrichs (2003a) and Leonardi et al. (2005) could imply that in the earlier studies milk protein was constrained by other factors than in our study, which may explain discrepancies among these studies.

\section{CONCLUSIONS}

Reducing the chop length of alfalfa and oat silage harvested using a New Holland forage harvester (model 790) from 19 to $6 \mathrm{~mm}$ reduced the geometric mean particle length from 14.2 to 10.9 and from 13.4 to 10.4 $\mathrm{mm}$, respectively. Incorporation of either $24 \%$ of DM longer chop or shorter chop alfalfa silage and either $24 \%$ of DM longer chop or shorter chop oat silage in TMR of lactating dairy cows that contained $52 \%$ of DM of barley grain-based concentrate showed that reducing the alfalfa chop length did not affect feed intake, whereas reducing the oat silage chop length increased DMI from to 19.4 to $21.2 \mathrm{~kg} / \mathrm{d}$. Reducing the chop lengths of alfalfa silage and oat silage chop length did not affect milk production, rumen fermentation, feeding behavior, meal patterns, or blood metabolites. Milk fat percentage was lower than milk protein percentage for all diets, suggesting that these diets induced SARA. This suggestion was supported by the rumen $\mathrm{pH}$, which was lower than 5.6 for more than $120 \mathrm{~min} / \mathrm{d}$ for all diets. 
The particle size distribution of the all diets did not suggest that cows were at risk for SARA. Despite this, SARA might have occurred due to the sorting against long feed particles in favor of short feed particles.

\section{ACKNOWLEDGMENTS}

The staff of the Glenlea Research Station, University of Manitoba, Terri Garner, and Janice Haines are thanked for their technical assistance. This study was supported by grants from Dairy Farmers of Canada (DFC), the Agri-Food Development Research Initiative (ARDI), and the Natural Sciences and Engineering Research Council of Canada (NSERC).

\section{REFERENCES}

AOAC. 1990. Official Methods of Analysis. 15th ed. AOAC, Arlington, VA.

Beauchemin, K. A. 1991. Effects of dietary neutral detergent fiber concentration and alfalfa hay quality on chewing, rumen function, and milk production of dairy cows. J. Dairy Sci. 74:3140-3151.

Beauchemin, K. A., M. Maekawa, and D. A. Christensen. 2002. Effect of diet and parity on meal patterns of lactating dairy cows. Can. J. Anim. Sci. 82:215-223.

Beauchemin, K. A., W. Z. Yang, and L. M. Rode. 2003. Effects of particle size of alfalfa-based dairy cow diets on chewing activity, ruminal fermentation, and milk production. J. Dairy Sci. 86:630-643.

Bhandari, S. K., K. H. Ominski, K. M. Wittenberg, and J. C. Plaizier. 2007. Effects of chop length of alfalfa and corn silage on milk production and rumen fermentation of dairy cows. J. Dairy Sci. 90:2355-2366.

Canadian Council of Animal Care (CCAC). 1993. Guide to the Care and Use of Experimental Animals. Ottawa, Ontario, Canada.

Clark, J. H., T. H. Klusmeyer, and M. R. Cameron. 1992. Microbial protein synthesis and flows of nitrogen fractions to the duodenum of dairy cows. J. Dairy Sci. 75:2304-2323.

Dado, R. G., and M. S. Allen. 1994. Variation in and relationships among feeding, chewing, and drinking variables for lactating dairy cows. J. Dairy Sci. 77:132-144.

Dairyland Laboratories. 2007. 2006 Forage summaries. http:// www.dairylandlabs.com/pages/interpretations/forage_2006. php Accessed Sept. 4, 2007.

DeVries, T. J., M. A. G. von Keyserlingk, D. M. Weary, and K. A. Beauchemin. 2003. Measuring the feeding behavior of lactating dairy cows in early to peak lactation. J. Dairy Sci. 86:3354-3361.

Duffield, T., J. C. Plaizier, A. Fairfield, R. Bagg, G. Vessie, P. Dick, J. Wilson, J. Aramini, and B. McBride. 2004. Comparison of techniques for measurement of rumen $\mathrm{pH}$ in lactating dairy cows. J. Dairy Sci. 87:59-66.

Edmonson, A. J., I. J. Lean, L. D. Weaver, T. Farver, and G. Webster. 1989. Body condition scoring chart for Holstein dairy cows. J. Dairy Sci. 72:68-78.

Gozho, G. N., J. C. Plaizier, D. O. Krause, A. D. Kennedy, and K. M. Wittenberg. 2005. Subacute ruminal acidosis induces ruminal lipopolysaccharide release and triggers an inflammatory response. J. Dairy Sci. 88:1399-1403.

Griinari, J. M., D. A. Dwyer, M. A. McGuire, D. E. Bauman, D. L. Palmquist, and K. V. Nurmela. 1998. Trans-octadecenoic acids and milk fat depression in lactating dairy cows. J. Dairy Sci. 81:1251-1261

Heinrichs, A. J., and P. J. Kononoff. 2002. Evaluating particle size of forages and TMRs using the New Penn State Forage Particle Separator. Cooperative Extension, College of Agricultural Sciences. 42:1-15.
Johnson, L. M., J. H. Harrison, D. Davidson, W. C. Mahanna, and K. Shinners. 2003. Corn silage management: Effects of hybrid, maturity, inoculation, and mechanical processing on fermentation characteristics. J. Dairy Sci. 86:287-308.

Kleen, J. L., G. A. Hooijer, J. Rehage, and J. P. Noordhuizen. 2003. Subacute ruminal acidosis (SARA): A review. J. Vet. Med. A Physiol. Pathol. Clin. Med. 50:406-414.

Kononoff, P. J., and A. J. Heinrichs. 2002. Evaluating particle size of forages and TMRs using the New Penn State Forage Particle Separator. DAS-02-042. College of Agricultural Sciences, Cooperative Extension. Penn State Univ., University Park, PA.

Kononoff, P. J., and A. J. Heinrichs. 2003a. The effect of reducing alfalfa haylage particle size on cows in early lactation. J. Dairy Sci. 86:1445-1457.

Kononoff, P. J., and A. J. Heinrichs. 2003b. The effect of corn silage particle size and cottonseed hulls on cows in early lactation. J. Dairy Sci. 86:2438-2451.

Kononoff, P. J., A. J. Heinrichs, and D. R. Buckmaster. 2003. Modification of the Penn State forage and total mixed ration particle separator and the effects of moisture content on its measurements. J. Dairy Sci. 86:1858-1863.

Kononoff, P. J., A. F. Mustafa, D. A. Christensen, and J. J. McKinnon. 2000. Short communication: Effects of barley silage particle length and effective fiber on yield and composition of milk from dairy cows. Can. J. Anim. Sci. 80:749-752.

Krause, K. M., and D. K. Combs. 2003. Effects of forage particle size, forage source, and grain fermentability on performance and ruminal pH in midlactation cows. J. Dairy Sci. 86:1382-1397.

Krause, K. M., D. K. Combs, and K. A. Beauchemin. 2002a. Effects of forage particle size and grain fermentability in midlactation cows. I. Milk production and diet digestibility. J. Dairy Sci. 85:1936-1946.

Krause, K. M., D. K. Combs, and K. A. Beauchemin. 2002b. Effects of forage particle size and grain fermentability in midlactation cows. II. Rumen $\mathrm{pH}$ and chewing activity. J. Dairy Sci. 85:1947-1957.

Kung, L., and R. Shaver. 2000. Interpretation and Use of Silage Fermentation Analysis Reports. http://www.dairylandlabs.com/ pages/interpretations/vfa.php. Accessed May 15, 2006.

Leonardi, C., and L. E. Armentano. 2003. Effect of quantity, quality, and length of alfalfa hay on selective consumption by dairy cows. J. Dairy Sci. 86:557-564.

Leonardi, C., K. J. Shinners, and L. E. Armentano. 2005. Effect of different dietary geometric mean particle length and particle size distribution of oat silage on feeding behavior and productive performance of dairy cattle. J. Dairy Sci. 88:698-710.

Maekawa, M., K. A. Beauchemin, and D. A. Christensen. 2002. Effect of concentrate level and feeding management on chewing activities, saliva production, and ruminal $\mathrm{pH}$ of lactating dairy cows. J. Dairy Sci. 85:1165-1175.

Merck. 2006. The Merck Veterinary Manual. 9th ed. Merck \& Co Inc., Rahway, NJ.

Mertens, D. R. 1997. Creating a system for meeting the fiber requirements of dairy cows. J. Dairy Sci. 80:1463-1481.

Mitlöhner, F. M., J. L. Morrow-Tesch, S. C. Wilson, J. W. Dailey, and J. J. McGlone. 2001. Behavioral sampling techniques for feedlot cattle. J. Anim. Sci. 79:1189-1193.

Plaizier, J. C. 2004. Replacing chopped alfalfa hay with alfalfa silage in barley grain and alfalfa based total mixed rations for lactating dairy cows. J. Dairy Sci. 87:2495-2505.

Plaizier, J. C., T. Garner, T. Droppo, and T. Whiting. 2004. Nutritional practices and water quality on Manitoba dairy farms. Can. J. Anim. Sci. 84:501-509.

Poppi, D. P., R. E. Hendrickson, and D. J. Minson. 1985. The relative resistance to escape of leaf and stem particles from the rumen of cattle. J. Agric. Sci. 105:9-14.

Rotger, A., A. Ferret, X. Manteca, J. L. Ruiz de la Torre, and S. Calsamiglia. 2006. Effects of dietary nonstructural carbohydrates and protein sources on feeding behavior of tethered heifers fed high-concentrate diets. J. Anim. Sci. 84:1197-1204.

SAS Institute. 1990. SAS User's Guide: Statistics. Version 6 ed. SAS Inst. Inc., Cary, NC. 
Soita, H. W., D. A. Christensen, J. J. McKinnon, and A. F. Mustafa. 2002. Effects of barley silage of different theoretical cut length on digestion kinetics in ruminants. Can. J. Anim. Sci. 82:207-213.

Stone, W. C. 2004. Nutritional approaches to minimize subacute ruminal acidosis and laminitis in dairy cattle. J. Dairy Sci. 87(E Suppl.):E13-E26.

Thomas, C., and J. M. Wilkinson. 1975. The utilization of maize silage for intensive beef production. 3. Nitrogen and acidity as factors affecting the nutritive value of the ensiled maize. J. Agric. Sci. (Camb.) 85:225-261.

Tolkamp, B. J., and I. Kyriazakis. 1999. To split behaviour into bouts, log-transform the intervals. Anim. Behav. 57:807-817.

Tolkamp, B. J., D. P. N. Schweitzer, and I. Kyriazakis. 2000. The biologically relevant unit for the analysis of short-term feeding behavior of dairy cows. J. Dairy Sci. 83:2057-2068.
Uden, P., P. E. Colucci, and P. J. Van Soest. 1980. Investigation of chromium, cerium, and cobalt as markers in digesta. Rate of passage studies. J. Sci. Food Agric. 31:632-635.

Van Soest, P. J., J. B. Robertson, and B. A. Lewis. 1991. Methods for dietary fiber, neutral detergent fiber, and nonstarch polysaccharides in relation to animal nutrition. J. Dairy Sci. 74:35833597.

Wang, Z., and L. A. Goonewardene. 2004. The use of MIXED models in the analysis of animal experiments with repeated measured data. Can. J. Anim. Sci. 84:1-11.

Yang, W. Z., and K. A. Beauchemin. 2006a. Effects of physically effective fiber on chewing activity and ruminal $\mathrm{pH}$ of dairy cows fed diets based on barley silage. J. Dairy Sci. 89:217-228.

Yang, W. Z., and K. A. Beauchemin. 2006b. Increasing the physically effective fiber content of dairy cow diets may lower efficiency of feed use. J. Dairy Sci. 89:2694-2704. 